INTERNATIONAL

FOOD POLICY

RESEARCH

INSTITUTE

IFPRI

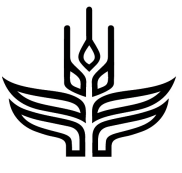

CGIAR

Policies, Institutions, and Markets

Led by IFPRI

IFPRI Discussion Paper 01904

December 2019

Land Reform and Child Health in the Kyrgyz Republic

Katrina Kosec

Olga N. Shemyakina

Development Strategy and Governance Division 


\section{INTERNATIONAL FOOD POLICY RESEARCH INSTITUTE}

The International Food Policy Research Institute (IFPRI), established in 1975, provides research-based policy solutions to sustainably reduce poverty and end hunger and malnutrition. IFPRI's strategic research aims to foster a climate-resilient and sustainable food supply; promote healthy diets and nutrition for all; build inclusive and efficient markets, trade systems, and food industries; transform agricultural and rural economies; and strengthen institutions and governance. Gender is integrated in all the Institute's work. Partnerships, communications, capacity strengthening, and data and knowledge management are essential components to translate IFPRI's research from action to impact. The Institute's regional and country programs play a critical role in responding to demand for food policy research and in delivering holistic support for country-led development. IFPRI collaborates with partners around the world.

\section{AUTHORS}

Katrina Kosec (k.kosec@cgiar.org) is a Senior Research Fellow in the Development Strategy and Governance Division of the International Food Policy Research Institute (IFPRI), Washington, DC.

Olga N. Shemyakina (olga.shemyakina@econ.gatech.edu) is an Associate Professor at the School of Economics, Georgia Institute of Technology, Atlanta, GA.

\footnotetext{
Notices

${ }^{1}$ IFPRI Discussion Papers contain preliminary material and research results and are circulated in order to stimulate discussion and critical comment. They have not been subject to a formal external review via IFPRI's Publications Review Committee. Any opinions stated herein are those of the author(s) and are not necessarily representative of or endorsed by IFPRI.

${ }^{2}$ The boundaries and names shown and the designations used on the map(s) herein do not imply official endorsement or acceptance by the International Food Policy Research Institute (IFPRI) or its partners and contributors.

${ }^{3}$ Copyright remains with the authors. The authors are free to proceed, without further IFPRI permission, to publish this paper, or any revised version of it, in outlets such as journals, books, and other publications.
} 


\title{
Land Reform and Child Health in the Kyrgyz Republic ${ }^{ \pm}$
}

\author{
Katrina Kosec \\ International Food Policy Research Institute \\ (IFPRI) \\ k.kosec@,cgiar.org
}

\author{
Olga N. Shemyakina ${ }^{ \pm+}$ \\ Georgia Institute of Technology \\ School of Economics \\ olga.shemyakina@econ.gatech.edu
}

December 30, 2019

\begin{abstract}
Does the establishment of private property rights to land improve child health and nutrition outcomes? We exploit a natural experiment in the Kyrgyz Republic following the collapse of socialism, whereby the government rapidly liquidated state and collective farms containing 75 percent of agricultural land and distributed it to individuals, providing 99-year transferrable use rights. We use household surveys collected before, during, and after the privatization reform and spatial variation in its timing to identify its health and nutrition impacts. We find that young children aged 0-5 exposed to land privatization for longer periods of time accumulated significantly greater gains in height and weight, both critical measures of long-term health and nutrition. Health improvements appear to be driven by increases in consumption of homeproduced food - suggesting that increased private control over household production may translate into increased consumption and thus health dividends for young children.
\end{abstract}

Keywords: human capital, health, nutrition, land reform, Central Asia, Kyrgyz Republic JEL classifications: I1, J1, O1

\footnotetext{
${ }^{ \pm}$We thank the CGIAR Research Program on Policies, Institutions, and Markets led by IFPRI, the Georgia Institute of Technology and NASA/GODDARD SPACE FLT CTR/MD grant for "Multi-scale Synthesis of Land Cover and Land Use, Climatic and Societal Changes in Drylands of Central Asia", and the Ministry of Finance of the Russian Federation under IFPRI's Collaborative Research and Capacity Strengthening Program for Enhancing Agricultural Productivity and Food and Nutritional Security in Central Asia for financial support. We are also grateful to the Life in Kyrgyzstan Study (LIKS) team for their support, which included adding questions on the timing of land reform to round 5 of that survey for the purposes of this study. We would further like to thank Kamiljon Akramov, Melissa Hidrobo, Jessica Heckert; Nicholas P. Magnan, Ellen McCullough, Roman Mogilevskii and Jo Swinnen for helpful comments. We thank Brian Holtemeyer and Jie Song for excellent research assistance. We also would like to thank conference and seminar participants at the International Conference on Agriculture, Food Security, and Nutrition in Eurasia, Dushanbe, Tajikistan, October 2017; Annual Meeting of the Southern Economics Association, Tampa, FL, November 2017; the ReSAKSS-Asia conference on "Agriculture and Rural Transformation in Asia: Past Experiences and Future Opportunities", Bangkok, Thailand, December 2017; International Association of Agricultural Economics annual meetings, Vancouver, Canada, July 2018; the Pacific Development Conference, USC, Los Angeles, CA, March 2019; and the University of Georgia, Athens, GA, October 2019.

The authors may be contacted at: Katrina Kosec, Senior Research Fellow, IFPRI, 1201 I Street, NW Washington, DC 20005, USA, k.kosec@cgiar.org, (202) 862-4663; and Olga Shemyakina, Associate Professor, School of Economics, Georgia Institute of Technology, Atlanta, GA, 30332, USA, olga.shemyakina@econ.gatech.edu, (323) 229-3180.
} 


\section{Introduction}

Does the establishment of private property rights to land improve child health and nutrition outcomes? There are strong theoretical reasons for such a relationship. Individuals' incentives to invest in land are predicated on their ability to recoup on those investments - which generally requires strong protection of property rights (Demsetz 1967; Alchian and Demsetz 1973; Besley 1995). Compared to either government or communal land ownership, secure, private land ownership should in theory stimulate investments in land. These investments might manifest themselves as a greater share of land devoted to long-term crops (Do and Iyer 2008; Holden et al. 2009; Fenske 2011), more engagement in non-farm activities (Do and Iyer 2008), construction and repair of soil conservation structures (Holden et al. 2009; Deininger et al. 2011), or greater use of land fallowing (Fenske 2011). The effects of strong property rights on investment may also extend to investments in the housing environment that have been linked to child health (Field 2005; Galiani and Schargrodsky 2010; Meeks 2018); for example, investments in electricity, improved water, sanitation, garbage disposal, air ventilation systems, and other residential improvements. Secure land tenure can also increase access to credit to make such investments (Feder et al. 1988; De Soto 2000) and can allow for gains from trade (through both land sales and rental) (Besley 1995). Formal, private property rights can further reduce child labor and increase market as opposed to home work for adults, potentially benefitting child health (Field 2007). And finally, beyond investments in land and labor market opportunities, individuals farming on communal land may or may not retain a sizeable share of production; if their share is small, they may benefit little from accessing communal land. Perhaps in recognition of these benefits, there is a growing number of reforms bringing about land tenure recognition in developing countries (Lawry et al. 2017).

Despite the potential for strengthened protection of private property rights — such as through land titling programs - to stimulate investments in land and improve smallholder welfare, however, the empirical evidence is mixed (Sitko et al. 2014). In practice, land titling programs have often failed to achieve objectives including boosting investment in land and housing, access to formal credit, and local revenues (Payne et al. 2009). Poor and marginalized households and communities are often least likely to benefit from such programs (Deininger and Binswanger 1999; Meren and Haller 2008; Deininger and Feder 2009; Ali et al. 2014). In large part, the poor fail to secure land rights due to information asymmetries between richer and poorer 
households which disproportionately spur land acquisition by the relatively rich (Jansen and Roquas, 1998), often for speculative purposes (Benjaminsen and Sjaastad, 2002; Peters, 2004). Land titling programs may also nullify important benefits of customary tenure systems, including their role as a social safety net (Lavigne-Delville, 2002; Meinzen-Dick and Mwangi, 2009; Yaro 2010). It is thus not clear whether the establishment of private property rights will necessarily be net beneficial for child health, compared to communal or government land ownership.

Much of the empirical evidence base on how private property rights affect child health and nutrition has focused on the degree of formality of rights (e.g., by exploiting randomized or quasi-randomized land titling programs) rather than the presence or absence of access to privately-owned land. The evidence is furthermore mixed. While some studies suggest that increasing the degree of formality of existing tenure rights through land titling increases children's weights in Argentina (Galiani and Schargrodsky 2004) and Peru (Vogl 2007), it does not appear to affect child height in either country, and it increases the incidence of overweight and obesity (Vogl 2007). ${ }^{1}$ Also, these studies consider the effects of urban land formalization in capital cities of a high-income (Argentina) and an upper-middle income (Peru) economies, ${ }^{2}$ and it is unclear whether their findings apply to the establishment of private property rights in rural, developing country contexts where children face severe health and nutrition deficiencies. Several studies show that offering formal land rights to women can empower them and improve both investments in children and child health (Quisumbing et al. 1996; Allendorf 2007; Menon et al. 2014; Burroway 2015) - providing evidence on the combined effects of secure land access and women's empowerment for child health outcomes.

We know of little empirical work considering the effects of private land access itself on child health; this paper seeks to fill that void. Specifically, we exploit a natural experiment in the Kyrgyz Republic following the collapse of socialism to identify the effects of land decollectivization, hereafter referred to as land privatization, on child health outcomes. Starting in the early 1990s and peaking during 1994-1995, the Government of the Kyrgyz Republic rapidly liquidated 262 state farms and 190 collective farms containing 75 percent of agricultural land (excluding pastureland) and distributed it to individuals, providing 99-year transferrable use rights. We exploit spatial variation in the timing of land privatization, making use of repeated

\footnotetext{
${ }^{1}$ Land titling does, however, lower the rate of teenage pregnancy (Galiani and Schargrodsky 2004).

${ }^{2}$ That optimal property rights systems may depend on income levels is suggested, for example, by Kremer et al. (2011) in the context of investments in health.
} 
cross-sectional Living Standards Measurement Study (LSMS) data from the Kyrgyz Republic from 1993, 1996, 1997, and 1998 to analyze the child health impacts of land privatization. Specifically, we compare children of the same age (in months) with different exposures to land privatization due to the timing of its roll-out. Because we have four rounds of data and spatial variation in the timing of privatization, we can include not only age in months fixed effects but also region (oblast) and survey year fixed effects.

Our analysis examines the health status of children $0-5$ years old (i.e., $0-60$ months old). As children are especially vulnerable in their first two years of life (Shrimpton et al. 2001; Carter and Maluccio 2003), we additionally always separately consider children aged 0-24 months and 25-60 months. To learn about whether there are any gendered effects of the land privatization, we also differentiate between effects on girls and on boys. Our primary health outcomes are the three most commonly used anthropometric indices used to measure health of young children: height-for-age z-scores (a measure of stunting and of long-term health and nutritional experience), weight-for-height z-scores (a measure of wasting), and weight-for-age zscores (another measure of long-term health and nutritional experience) (WHO 1997). We consider the impacts of exposure to land privatization on these outcomes as well as on household food and non-food consumption and on land access itself.

We find that young children exposed to land privatization for longer periods of time accumulated significantly greater gains in height and weight, both critical measures of long-term health and nutrition. Specifically, height-for-age z-scores and weight-for-age z-scores of children aged $0-5$ are increasing in the number of months of exposure. This effect appears to be driven predominately by children aged $0-24$ months old; while impacts on those aged $25-60$ months old are smaller in magnitude and statistically insignificant. We find no overall impacts on weight-for-height z-scores, a measure of wasting, though we do find some reductions in wasting due to privatization for children aged $25-60$ months old. We find no evidence of significant gender differences in the effects of privatization. The effects appear to be driven predominately by increased consumption of food produced at home rather than increased consumption of purchased food or increases in non-food expenditures that may support health improvements in other ways (e.g., increased expenditure on medical care).

This study makes two main contributions. First, it provides some of the first causal evidence to our knowledge on the implications of a rapid change from government to private management and ownership of land on the health of young children. It does so by examining not 
a gradual change in institutions or in the degree of tenure security — both of which may be endogenous to a multitude of other factors affecting child health when exposure to them is not determined experimentally or quasi-experimentally—but by exploiting a natural experiment occurring with the collapse of the Soviet Union involving the rapid and near total privatization of previously government owned and managed land. Our findings have broad-reaching implications for the likely impacts of allocating land and land user rights to individuals instead of governments or communities in developing countries worldwide. Second, we contribute to a growing literature identifying the policy factors that can contribute to young children's health and nutrition during critical periods in their lives when they are most vulnerable to external shocks. Our results provide evidence on how changes in government management of land may influence young children's health and nutrition as well as through which mechanism.

The remainder of the paper is organized as follows: Section 2 presents our conceptual framework, pointing to theoretical ambiguity about the likely effect of privatizing land access on child health outcomes. Section 3 provides background information on the collapse of socialism, land privatization, and child health in the Kyrgyz Republic. Section 4 describes the empirical strategy, data, and outcomes of interest. Section 5 characterizes our main empirical results. Finally, Section 6 concludes and discusses implications for future research.

\section{Conceptual Framework}

Young children — especially those under age five — are especially sensitive to investments made in their health, including providing them with access to a sufficient and sufficiently diverse diet. Access to major productive resources such as land when they are young may thus play a critical role in determining their health outcomes through consumption and other channels. Government efforts to establish private property rights for the rural poor may be one means of providing them with greater access to land, or access to more productive land. Access to land tends to reduce out-migration and increases the likelihood of working in agriculture, especially in settings where land rental markets are underdeveloped (Kosec et al. 2018). While there is a direct relationship between farm size and productivity in many developed countries, there is generally an inverse 
relationship in labor-abundant developing countries (Lipton 2009). ${ }^{3}$ Also, if individuals farming on communal land do not retain a sizeable share of production, or if their share is small, they may benefit little from accessing communal land. Thus, secure access to privately-held land may lead individuals to work in agriculture and to produce and thus consume more - thus benefiting child welfare. Where food markets are imperfect, land can also serve as a source of cheaper food relative to the market, reducing poverty and undernutrition (Burgess 2001). And if private land access allows for greater diversity of agricultural production, this increased diversity may in some cases translate into higher-quality and more diverse diets, thus benefiting health (Arimond and Ruel 2004; Jones et al. 2014; Dillon et al. 2015; Sibhatu et al. 2015).

At the same time, there are potential costs of private as opposed to government or communal ownership of land. For households, these include physically demarcating and delineating plots, and the time involved in seeking titles or otherwise defending one's claim to land. For governments, they include establishing and maintaining land ownership records, enforcing land rights, and resolving disputes (Feder and Feeney 1991; DeMeza and Gould 1992; Deininger and Feder 2001). Beyond any productivity differences, potential advantages of collective farms include economies of scale in risk management, input purchasing, and marketing, as well as increased access to information and credit (Putterman 1985; Carter 1987; Deininger 1995; Mathijs and Swinnen 1998; Pryor 2014). These features may translate into greater productivity and thus, potentially, child welfare. A number of scholars have also challenged the value of private property rights, showing that many groups can successfully collectively govern common pool resources (Boyd et al. 2018). Thus, there is theoretical ambiguity about the ultimate impacts of establishing private property rights to land on child health and nutrition outcomes.

\footnotetext{
${ }^{3}$ This pattern comes from the smaller farms' advantage in managing labor (e.g., in seeking and screening workers, allocating tasks, training, and supervising), while large farms have an advantage in managing capital (e.g. hiring or buying a tractor). This difference may manifest itself as following: small farms having a higher percentage of land area cultivated (Kay 1998), a higher cropping intensity on cultivated land (Agrawal 2000), or a higher-value cropping pattern (e.g., using land for labor-intensive staples, vegetables, trees, and grazing) (Boyce 1987; van den Brink et al. 2006).
} 


\section{Background}

The Soviet era in the Republic of Kyrgyzstan spanned from 1917 to 1991; the country declared its independence from the Soviet Union in August 1991. Our study focuses on children in rural parts of the Kyrgyz Republic who were aged 0-5 during household surveys which took place over 1993-1998, and thus born in the decade between 1988 and 1998. They form a microgeneration of children who experienced the collapse and short-term aftermath of a long period of Soviet rule. Livelihoods in the rural Kyrgyz Republic evolved rapidly during this time period. During the Soviet era, the law formally allowed two forms of collective ownership in agriculture: sovkhozes were state owned enterprises that employed workers similarly to a Western corporation, and kolkhozes were collectively owned and managed enterprises that members entered into voluntarily, and which then shared profits with their members. Reportedly, there were no real differences between the two (Bloch, 2002). Thus, land was collectively owned and managed. This institutional arrangement changed rapidly in the 1990s, as we describe below.

In May 1993, the newly named Kyrgyz Republic joined the Commonwealth of Independent States. The Kyrgyz Republic is a land-locked, low-income country in Central Asia that is only about 200 thousand square kilometers. Its population in 1990 was approximately 4.4 million, and reached 4.8 million in 1998. It is comprised of seven regions, or oblasts, in addition to the independent cities of Bishkek (the capital) and Osh. ${ }^{4}$ In 1988, the Kyrgyz Republic had a GDP per capita of $\$ 1050$, which rose to $\$ 1096$ in 1990, only to plummet to $\$ 535$ by 1995 (all values in constant 2010 USD). The economy grew steadily over the course of the next two decades, but as of 2017, GDP per capita was still slightly short of its 1990 level (World Bank 2017).

Agriculture is critical to the economy of the Kyrgyz Republic. Throughout 1988-1998, between 62 and 64 percent of the country's population lived in rural areas. Agriculture's share in GDP was 31 percent in 1988, rose to a peak of 46 percent in 1996, and then declined to 36 percent by 1998 (World Bank 2017). Corresponding to these trends, the share of male employment in agriculture in 1988 was 34 percent, and it steadily rose to 49 percent by 1998 . These values are large, especially for a country where arable land constitutes only seven percent of total land (World Bank 2017), these patterns suggest low productivity in agriculture as well as

\footnotetext{
${ }^{4}$ In addition to Osh being a large city, there is also an oblast named Osh. Given our focus on rural areas, it is this oblast, rather than the independent city of Osh, to which we refer in Table 1 and analyze throughout.
} 
a lack of other employment opportunities during that time. In 1998, 8.6 percent of children aged 7-14 were employed-94.5 percent of them in agriculture. All Central Asian countries experienced negative growth in gross agricultural production in the early 1990s, including the Kyrgyz Republic (Bloch 2002). However, by 1998, among all Central Asian countries, only the Kyrgyz Republic had exceeded its Soviet-era (1989-1991) agricultural production; by contrast, Kazakhstan and Tajikistan each achieved slightly under half of their Soviet-era levels (Bloch 2002).

Along with five other Central Asian countries that similarly gained their independence with the breakup of the Soviet Union in 1991, the Kyrgyz Republic initiated a process of transition to a market economy in the agricultural sector that included land reform policies aimed at making agriculture an engine for economic growth (Bloch 2002; FAO 2015). However, of the five, the Kyrgyz Republic has been noted for being the most aggressive in its approach to restructuring agricultural enterprises, privatizing land, and promoting private farming (Bloch and Rasmussen 1998). Other countries pursued more gradual approaches. In Kazakhstan, the reform was the slowest paced, as farmers who received land were supposed to give it back to a cooperative and farm in the same way as kolkhozes or sovhozes used to operate. Privatization in the Kyrgyz Republic in contrast placed few requirements on farmers. Acquiring land from the government was not conditional on farmers continuing to sell their crops to the government boards at set prices (as was done in Tajikistan and Turkmenistan); farmers were not restricted in producing products based on government orders (as in Tajikistan and Turkmenistan); and farmers did not face penalties for not using or improving their land within a certain time (as in Turkmenistan).

In the post-Soviet Kyrgyz Republic, land reform involved taking land that was in collective ownership and distributing it in the form of parcels of land or farm shares to former members of kolkhozes and sovkhozes. This process stands in contrast to many other land reforms that involve redistributing land from wealthy landowners and giving it to individuals (i.e., movement from one form of private ownership to another). The reform proceeded swiftly but unevenly across the country. Starting in the early 1990s and peaking during 1994-1995, the government rapidly liquidated 262 state farms and 190 collective farms containing 75 percent of the country's agricultural land (excluding pastureland) and distributed it to individuals. In effect, this process initiated the privatization of land, and we therefore refer to it as the Kyrgyz Republic's land privatization. All farm residents were eligible to receive land distributions, and 
farm workers were eligible to receive farm equipment (World Bank 1998). The amount provided to each farmer was based on their employment status, farming experience, and proximity to the farm (USAID 2011). Also, only residents who lived in the area for at least two years were eligible to receive land. Individuals received 99-year transferrable use rights for land shares ranging from 0.1 to 1 hectares. In 1998, a constitutional amendment allowed for private land ownership, and all land use certificates were transformed into land ownership certificates (USAID 2011). The government did impose some market restraints on land sales; for example, land plots were indivisible even if a buyer and seller could otherwise agree on the sale of part of the plot. This feature may have contributed to the primary land market being rentals of land plots - which typically occurred through informal (unregistered) rental arrangements (USAID 2005).

Overall, the reform vastly improved individuals" "freedom to farm" - that is, their ability to decide what to plant and when, which inputs to apply, and to whom to sell their production and at what price. Households could also make their own decisions regarding the optimal mix of agriculture and livestock rearing. This change was in marked contrast to rural agriculture during the Soviet era, in which individuals supplied labor to collective farms and were compensated monetarily and in kind for their labor, but largely removed from all decisions about how to farm.

Land privatization in the Kyrgyz Republic did not proceed all at once across the full country given the obvious logistical challenges of a simultaneous reform. The initial land reform started in the early 1990s but was quickly put on hold due to concerns about unfairness in land distribution across different ethnicities and unsustainably high input prices for farmers (World Bank 1993). Between 1990-1991 and 1996-1997, the number of private farms rose from zero to 38,218 while the number of collective farms declined from 518 to 22 (World Bank 1998, p. 12). ${ }^{5}$ In some places, large farms reportedly split quickly into very small one-household farms, whereas in other places, reform stalled for years (Mogilevskii 2016).

To learn about the pattern of privatization over time and space, we included a question on the community questionnaire of the 2016 Life in Kyrgyzstan Survey (LIK) asking, "In the 1990s, a large-scale land reform occurred in the Kyrgyz Republic that allocated land plots to households. When did the land reform first allocate plots of land in your community (month and year)?" The survey covered between 4 and 27 rural communities in each oblast. We took the

\footnotetext{
${ }^{5}$ The relevant legislation and pattern of land reform are described in more detail in World Bank (1998).
} 
median date (month and year) in each oblast and assigned this as the date of the reform; these dates are shown in Table 1. The dates of privatization range from September 1992 to January 1996 - a period of three years and five months. Existing sources provide little explanation for the exact spatial pattern in the timing of land reform that transpired. Given the likelihood that the timing of reform was due to unobserved, region-specific factors, we include region fixed effects in all analyses.

Table 1: Date of Land Reform

\begin{tabular}{lr}
\hline Oblast & Date of reform. \\
\hline Batken $^{6}$ & Jan-96 \\
Chui & Dec-94 \\
Issyk-Kul & Feb-95 \\
Jalal-Abad & Mar-94 \\
Naryn & Sep-92 \\
Osh & May-94 \\
Talas & Mar-94 \\
\hline Notes: The date of reform is calculated by \\
the authors from the Life in Kyrgyzstan \\
survey conducted in 2016. The date is a \\
median date reported by Life in Kyrgyzstan \\
survey participants.
\end{tabular}

Clearly, land privatization did not take place immediately in the month and year in which individuals recognize that land reform occurred in their oblast. It is possible that restrictions relaxed and individuals began to farm plots as if they were individual plots prior to the reform being perceived as officially permitting private land management. It is also possible that even after reform occurred, it took some time for individuals to access individual plots-either due to administrative delays or individuals' own slowness in petitioning government for land. Lacking further information on what aspects of reform specifically had been initiated at the time land privatization occurred, we carry out analysis (Appendix Table A6) that perturbs the data of privatization - either one year forward, or one year backward - to observe whether the effects are larger or smaller when allowing for either anticipatory or lagged effects of reform.

Following the early 1990s land reforms and accompanying tenure security, crop production by 19 percent between 1992 and 1998 (World Bank 2017), ${ }^{7}$ suggesting

\footnotetext{
${ }^{6}$ Note that Batken oblast is not on the list of oblasts that were included for sampling for the LSMS surveys used in this paper (1994, 1996, 1997 and 1998) (World Bank 1996, 2002).

${ }^{7}$ The crop production index increased from 64.7 to 76.97 , the food production index increased from 78.1 to 85.1 , and the livestock production declined from 108.6 to 92.6 over 1992 to $1998(2004-2006=100)$.
} 
improvements in productive capacity. However, the number of tractors per 100 square kilometers of arable land was effectively unchanged over the same period, rising only from 189.4 to 189.8, providing little evidence of greater mechanization. Cereal yields (kilograms per hectare) in particular declined slightly by about 10 percent during 1992 - 1998. Further, livestock production - a significant share of agricultural production value in the Kyrgyz Republicdecreased by 15 percent during 1992 - 1998, suggesting that increases in crop agriculture did not necessarily extend to livestock (World Bank 2017). These trends reflect the fact that the vast majority of agricultural production became concentrated in small, individual farms (FAO 2015); new farmers may have lacked the resources to farm as efficiently as was done previously on large, collective farms (Jones 2004).

\section{Empirical Strategy}

\section{A. Data}

Our main data source consists of four repeated cross-sections of Living Standards Measurement Study (LSMS) data for the Kyrgyz Republic: 1993, 1996, 1997, and 1998. Each survey was nationally representative and carried out during the months of October - November. ${ }^{8}$ These data are optimally suited to answer our research questions for several reasons. First, roughly the same sampling methodology, geographical coverage, and questions about our outcomes of interest and relevant control variables were asked in all four rounds, allowing us to compare otherwise similar households and children at different points in time. Second, the data are generally of high quality; they were collected by the National Statistical Committee (NATSTATCOM) with technical assistance from the World Bank, and are well documented, translated into English, and publicly downloadable from the World Bank's website (World Bank 1993). Finally, these data importantly span the critical period during which land privatization occurred (i.e., between September 1992 and January 1996). The differences in the timing of land privatization illustrated in Table 1 mean that privatization had not yet occurred all over the country at the time of the 1993 survey (except for Naryn oblast), but had been in place for varying amounts of time when

\footnotetext{
${ }^{8}$ The 1996 survey was split between two time periods — one in early 1996 and one in late 1996 . We use the data collected during October - November 1996 in our analysis.
} 
the 1996, 1997, and 1998 surveys took place. This feature allows us to employ both oblast and year fixed effects, as we explain in more detail below.

Figure 1 depicts visually how young children's (age $0-5$ ) exposure to land privatization varies across our four rounds of repeated cross sections according to child age in years. While in 1993, few children were exposed and exposure was not highly correlated with age, exposure grew significantly by 1996, as did variation in the length of exposure even within a given year of age. By 1998, exposure was close to being predominately a function of child age, as land privatization had occurred everywhere by January 1996. Appendix Figure A1 displays these patterns in further detail, showing how they vary across oblasts that comprise our sample; here, we see not only the temporal but also the spatial variation in exposure more clearly.

Figure 1: Exposure to land privatization by child age in years, over the four survey years

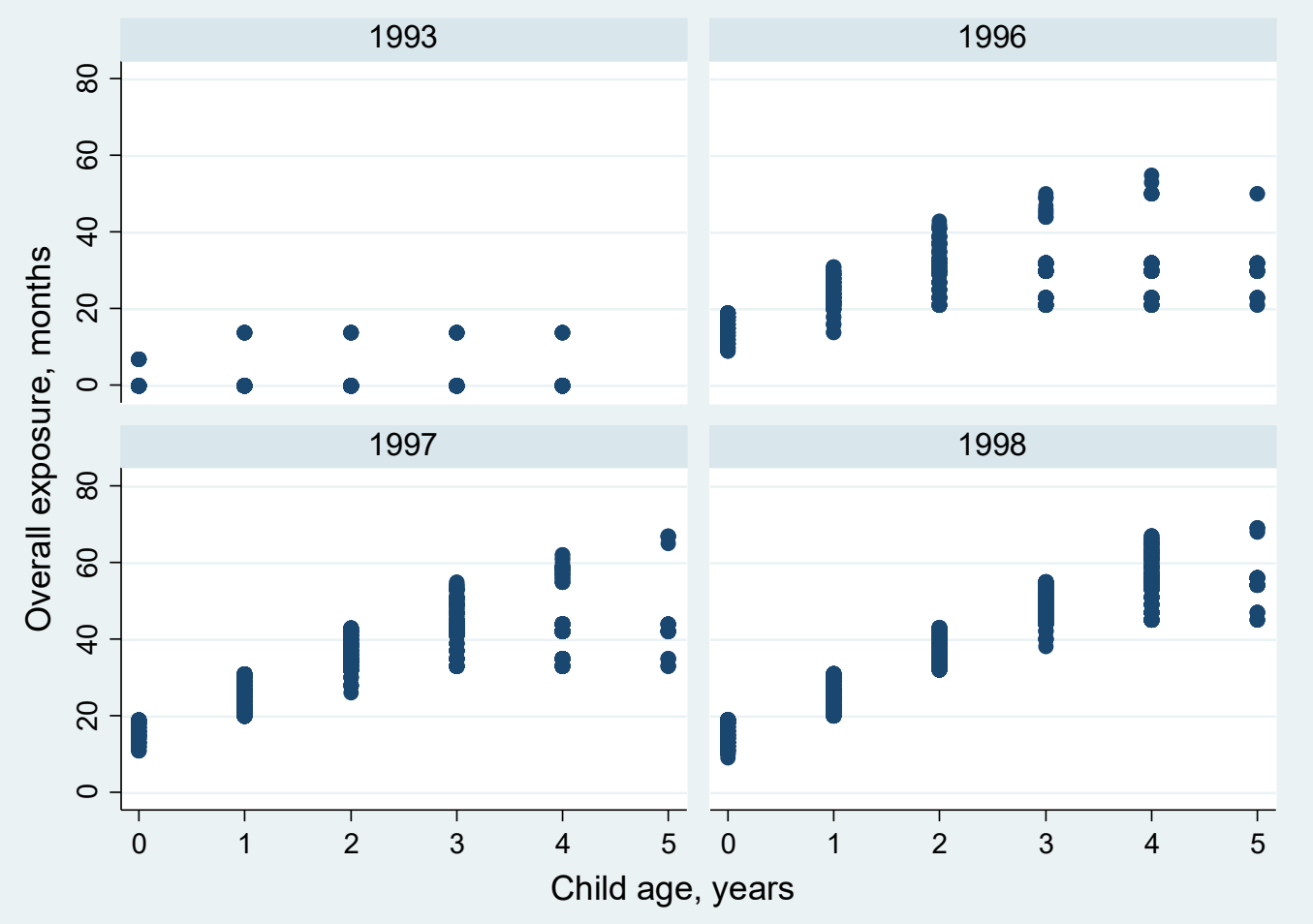

Notes: Overall exposure includes exposure to land reform between 0 and 60 months of age and exposure in utero.

Source: World Bank LSMS (1993, 1996, 1997, and 1998).

We focus on children living in rural areas, where agriculture is important to livelihoods and households were eligible to receive land from the reform (those living in urban areas were ineligible). Our analysis examines the health and nutritional status of children aged $0-5$ years 
old in addition to separately considering children aged 0-24 months and 25-60 months. We have data on these children's gender, height, whether they were measured laying down or standing, weight, and age in years for all four years. For 1996, 1997, and 1998, we further know both the year and month of birth. Date of visit is not consistently available, but given the fairly short window of enumeration for each survey (i.e., during October - November), we assume a November $1^{\text {st }}$ date of visit (the midpoint) and compute age in months accordingly. For 1997 and 1998, we further know the exact day of birth. In all years, we use all of information available to us about timing of birth to compute children's ages and anthropometric measurements. ${ }^{9}$ As such, measurement error in our anthropometric measurements is decreasing over time. Appendix Table A1 clarifies the data we have in each year and the calculations we accordingly make to compute children's ages as precisely as possible.

Our child age data are imperfect, and we acknowledge them as a caveat for our empirics. However, we know of no other surveys carried out during the Kyrgyz Republic's historic land privatization, making these the best data available to us. We argue that the noise in our estimates of child age in months constitutes random measurement error and should thus not bias our estimates of the effects of privatization on child health and nutrition. If anything, we would expect this random measurement error to make it harder to pick up statistically significant effects. Importantly, we also show the robustness of our main results to omitting 1993 - the year for which our knowledge of the timing of birth is the least precise - and thus using only 1996, 1997, and 1998 data (results reported in Appendix Table A2). While these regressions do not include any children that were completely unexposed to privatization - since the last oblast to privatize did so in January 1996 - we can compare children of the same age in months with different exposures due to both the timing of privatization (and the spatial variation in it) and the year of survey data considered (1996, 1997, or 1998).

All of our econometric specifications control for child age (dummies age in months) and gender. Our baseline econometric specifications further control for several characteristics of the household head: their age, gender, marital status, and ethnicity (Kyrgyz, Russian, Uzbek, or “other”). Table 2 summarizes these control variables for our child-level sample, for each survey

\footnotetext{
${ }^{9}$ For 1993, we do so by assuming that May (i.e., 6 months before the survey date of November) is the month of birth. A simple examine illustrates why: assume a child is 3 years old at the time of the November 1993 survey. We know that her age in months must be between 36 and 47 (if it were 35, she would be 2 years old, and if it were 48 , she would be 4 years old). We thus assume that she is 42 months old in November 1993 (since $(36+47) / 2=42$ when rounded to the nearest integer), implying that she turned 3 in May 1993 (her birth month).
} 
round and for all rounds pooled together. In the pooled sample of all $0-5$ year olds, 48 percent of children are female and 80 percent live in male-headed households. The average birth year is 1994. Average exposure to privatization since birth is 19.74 months; the corresponding figures for $1993,1996,1997$, and 1998 individually are $0.12,15.63,24.44$, and 30.08 months, respectively.

Table 3 summarizes variables at the household-level. Across all survey years, the average rural household has 5.57 members. About 88 percent of households report having access to land (pooling all years) - though we note the caveat that the survey question did not specify that the land was privately-held, and it could have been understood by some to include communal land or land in the form of small kitchen gardens (i.e., small areas typically adjacent to private houses). Indeed, a full 71 percent of households already indicated having land access as of 1993, a period pre-dating privatization for most of the sample. However, a follow-up question which asked about the size (in hectares) of the plot(s) of land to which the household had access casts doubt on the interpretation of the access question as including communal land. Across all rounds, the average amount of land to which individuals had access was 1.26 hectares; during 1996-1998, this amount was an even higher at 1.47 hectares. ${ }^{10}$ However, it was only 0.30 hectares at the time of the 1993 survey-likely reflecting access to small kitchen gardens, rather than to larger plots of land that were actually communally controlled. Further, the share of rural households claiming that they had access to land grew to above 88 percent by 1996, where it remained for the next two years - suggesting that many households claiming no access to land in 1993 obtained it over the next 3-5 years.

Food expenditures constitute a full 65 percent of total household expenditure, indicating the level of poverty of our rural households. A large share of food consumption - about 41 percent - also comes from home production, indicating the importance of land for households' diets. Thus, individual land access should in theory heavily affect young children's health in this very poor context.

\footnotetext{
10 This value is the weighted (by sample size in each year) average of hectares accessed on average in 1996, 1997, and 1998.
} 
Table 2 - Summary Statistics in a Sample of 0-5 year olds

\begin{tabular}{|c|c|c|c|c|c|c|c|c|c|c|}
\hline \multirow[b]{2}{*}{ Variables } & \multicolumn{2}{|c|}{ All Surveys } & \multicolumn{2}{|c|}{1993 survey } & \multicolumn{2}{|c|}{1996 survey } & \multicolumn{2}{|c|}{1997 survey } & \multicolumn{2}{|c|}{1998 survey } \\
\hline & Obs & Mean & Obs & Mean & Obs & Mean & Obs & Mean & Obs & Mean \\
\hline & $(1)$ & $(2)$ & (3) & $(4)$ & $(5)$ & $(6)$ & $(7)$ & $(8)$ & $(9)$ & $(10)$ \\
\hline Height-for-age Z-score & 3,335 & -1.36 & 652 & -0.34 & 632 & -1.34 & 919 & -1.80 & 1,132 & -1.60 \\
\hline Weight-for-age Z-score & 3,823 & 0.03 & 712 & 0.60 & 725 & 0.06 & 1,065 & -0.23 & 1,321 & -0.09 \\
\hline Weight-for-length(height) Z-score & 3,072 & 0.83 & 663 & 0.71 & 573 & 1.12 & 840 & 0.76 & 996 & 0.81 \\
\hline $\begin{array}{l}\text { Months in utero during reform } \\
\text { Months exposed to reform during }\end{array}$ & 4,136 & 4.69 & 824 & 0.02 & 777 & 3.63 & 1,146 & 5.65 & 1,389 & 7.26 \\
\hline life (btw 0 and 60 months) & 4,136 & 23.95 & 824 & 0.74 & 777 & 23.37 & 1,146 & 29.71 & 1,389 & 33.28 \\
\hline $\begin{array}{l}\text { Months exposed overall (including } \\
\text { in utero period }\end{array}$ & 4,136 & 28.63 & 824 & 0.76 & 777 & 26.99 & 1,146 & 35.36 & 1,389 & 40.54 \\
\hline Age in months & 4,136 & 32.74 & 824 & 30.96 & 777 & 32.20 & 1,146 & 32.77 & 1,389 & 34.06 \\
\hline Child is female & 4,136 & 0.48 & 824 & 0.48 & 777 & 0.49 & 1,146 & 0.47 & 1,389 & 0.49 \\
\hline Birth year & 4,136 & 1994.04 & 824 & 1990.92 & 777 & 1993.69 & 1,146 & 1994.66 & 1,389 & 1995.56 \\
\hline HH head age & 4,113 & 46.30 & 824 & 43.84 & 771 & 44.93 & 1,136 & 47.81 & 1,382 & 47.28 \\
\hline $\mathrm{HH}$ head is female & 4,117 & 0.20 & 824 & 0.35 & 772 & 0.15 & 1,139 & 0.16 & 1,382 & 0.16 \\
\hline $\mathrm{HH}$ head is married & 4,117 & 0.81 & 824 & 0.85 & 772 & 0.82 & 1,139 & 0.80 & 1,382 & 0.80 \\
\hline HH head - Kyrgyz & 4,118 & 0.83 & 824 & 0.74 & 777 & 0.79 & 1,137 & 0.94 & 1,380 & 0.83 \\
\hline HH head - Russian & 4,118 & 0.03 & 824 & 0.03 & 777 & 0.04 & 1,137 & 0.02 & 1,380 & 0.03 \\
\hline HH head - Uzbek & 4,118 & 0.07 & 824 & 0.12 & 777 & 0.10 & 1,137 & 0.01 & 1,380 & 0.09 \\
\hline HH head other ethnic group & 4,118 & 0.06 & 824 & 0.11 & 777 & 0.08 & 1,137 & 0.04 & 1,380 & 0.05 \\
\hline $\mathrm{HH}$ has land & 4,114 & 0.90 & 822 & 0.73 & 777 & 0.90 & 1,143 & 0.99 & 1,372 & 0.92 \\
\hline Hectares of land in $\mathrm{HH}$ possession & 4,109 & 1.47 & 817 & 0.18 & 777 & 3.54 & 1,143 & 1.37 & 1,372 & 1.16 \\
\hline Born before $1995 \& \mathrm{HH}$ has land & 4,114 & 0.48 & 822 & 0.73 & 777 & 0.60 & 1,143 & 0.47 & 1,372 & 0.26 \\
\hline
\end{tabular}

Source: World Bank LSMS (1993, 1996, 1997 and 1998).

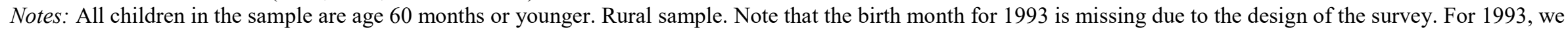

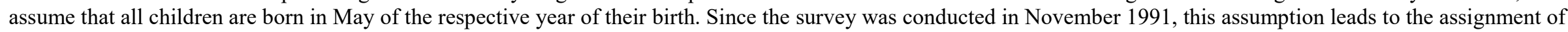

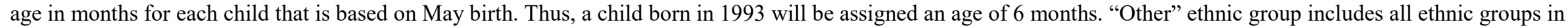
the Kyrgyz Republic other than Kyrgyz, Russian, and Uzbek. 


\section{Table 3: Household-level summary statistics}

\begin{tabular}{|c|c|c|c|c|c|c|c|c|c|c|}
\hline \multirow[b]{2}{*}{ Variable } & \multicolumn{2}{|c|}{ All Surveys } & \multicolumn{2}{|c|}{1993 survey } & \multicolumn{2}{|c|}{1996 survey } & \multicolumn{2}{|c|}{1997 survey } & \multicolumn{2}{|c|}{1998 survey } \\
\hline & Obs & Mean & Obs & Mean & Obs & Mean & Obs & Mean & Obs & Mean \\
\hline & $(1)$ & $(2)$ & $(3)$ & $(4)$ & $(5)$ & $(6)$ & $(7)$ & $(8)$ & $(9)$ & $(10)$ \\
\hline \multicolumn{11}{|l|}{ Household expenditure (som), 30 days, deflated, 1995=100 } \\
\hline Food expenditure & 6132 & 577.06 & 1,108 & 1437.43 & 1,203 & 398.67 & 1,759 & 482.27 & 2,062 & 299.68 \\
\hline Food: home produced \& consumed crops \& animal products & 6034 & 1029.04 & 1,108 & 2589.90 & 1,199 & 350.13 & 1,681 & 311.35 & 2,046 & 1171.28 \\
\hline Total food consumption & 6034 & 1607.38 & 1,108 & 4027.33 & 1,199 & 749.25 & 1,681 & 789.10 & 2,046 & 1472.05 \\
\hline Expenditure on non-food & 6132 & 551.38 & 1,108 & 774.88 & 1,203 & 509.73 & 1,759 & 539.75 & 2,062 & 465.52 \\
\hline Total food \& non-food expenditure & 6034 & 2159.57 & 1,108 & 4802.21 & 1,199 & 1259.58 & 1,681 & 1327.53 & 2,046 & 1939.49 \\
\hline Share of home produced food in total food & 5992 & 0.41 & 1,070 & 0.53 & 1,197 & 0.30 & 1,680 & 0.42 & 2,045 & 0.40 \\
\hline Share of food expenditure in total consumption & 6012 & 0.65 & 1,086 & 0.88 & 1,199 & 0.59 & 1,681 & 0.63 & 2,046 & 0.59 \\
\hline Months HH was exposed to land reform & 6231 & 36.86 & 1,108 & 0.88 & 1,203 & 29.40 & 1,760 & 42.91 & 2,160 & 54.53 \\
\hline Household size & 6034 & 5.57 & 1,108 & 5.71 & 1,199 & 5.06 & 1,681 & 5.71 & 2,046 & 5.67 \\
\hline $\mathrm{HH}$ head is male & 6034 & 0.80 & 1,108 & 0.87 & 1,199 & 0.77 & 1,681 & 0.79 & 2,046 & 0.77 \\
\hline $\mathrm{HH}$ head is Kyrgyz & 6034 & 0.76 & 1,108 & 0.66 & 1,199 & 0.69 & 1,681 & 0.86 & 2,046 & 0.76 \\
\hline $\mathrm{HH}$ head is Russian & 6034 & 0.11 & 1,108 & 0.13 & 1,199 & 0.14 & 1,681 & 0.07 & 2,046 & 0.11 \\
\hline $\mathrm{HH}$ head is Uzbek & 6034 & 0.05 & 1,108 & 0.09 & 1,199 & 0.08 & 1,681 & 0.01 & 2,046 & 0.05 \\
\hline $\mathrm{HH}$ head- other ethnic group & 6034 & 0.08 & 1,108 & 0.12 & 1,199 & 0.09 & 1,681 & 0.06 & 2,046 & 0.07 \\
\hline
\end{tabular}

Source: World Bank LSMS (1993, 1996, 1997 and 1998).

Notes: The date of land reform (to calculate months a household was "exposed" to reform) is based on 2016 Life in Kyrgyzstan survey (which provided the month and year). "other ethnic status" is a reference category. Sample: households in rural areas. All expenditure values for 1996/1997/1998 were calculated using methods outlined in World Bank (2002). The home production and consumption values for 1993 survey were calculated by the World Bank staff (World Bank 1996). All expenditure values are in Kyrgyz som, deflated using World Bank GDP deflator data for the Kyrgyz Republic, with base year 1995.

https://data.worldbank.org/indicator/NY.GDP.DEFL.ZS (Accessed: July 28, 2018). 


\section{B. Outcomes}

Our primary health outcomes are the three most commonly used anthropometric indices for children: height-for-age z-scores (a measure of stunting and of long-term health and nutritional status), weight-for-height z-scores (a measure of wasting), and weight-for-age z-scores (another measure of long-term health and nutritional experience) (WHO 1997). We compute these using the 2006 WHO child growth standards and the Stata program zscore06 (Leroy 2011). Table 2 summarizes these outcome variables, while Figures $2-4$ show kernel density plots of each of the three measures for each survey year, separately. What is most clear is that height-for-age zscores (HAZ) and weight-for-age z-scores (WAZ) worsened between 1993 (prior to land privatization for all oblasts except Naryn) and subsequent years. That is, they reflect a general pattern of deterioration in young children's anthropometrics during the time period of land reform. This pattern reflects the costs of the transition period more broadly, rather than land reform specifically, and our econometric strategy — which we turn to next — explicitly aims to disentangle of the effects of the two by accounting for year trends and exploiting spatial variation in exposure.

Figure 2: Height for age z-scores (HAZ)

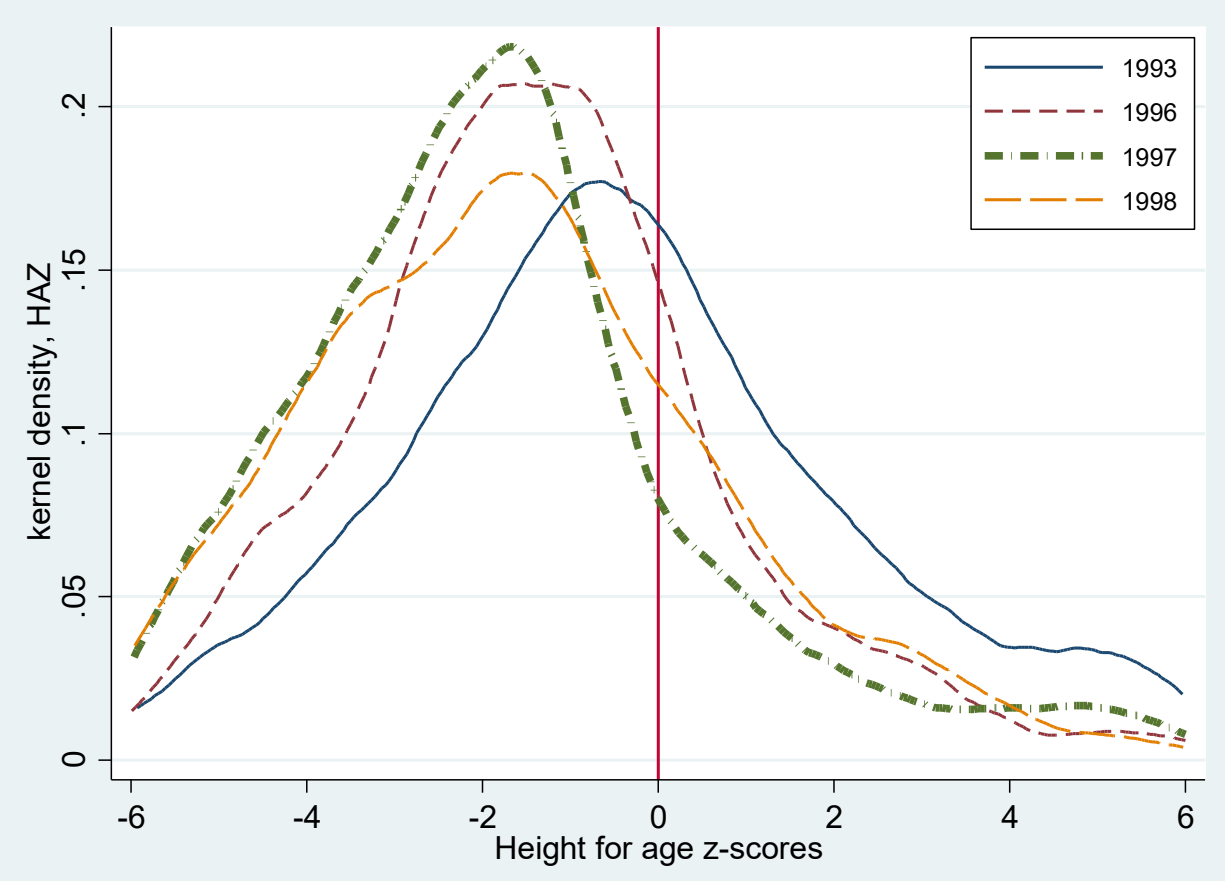

Notes: As for Figure 1. Source: as for Figure 1. 
Figure 3: Weight for age z-scores (WAZ)

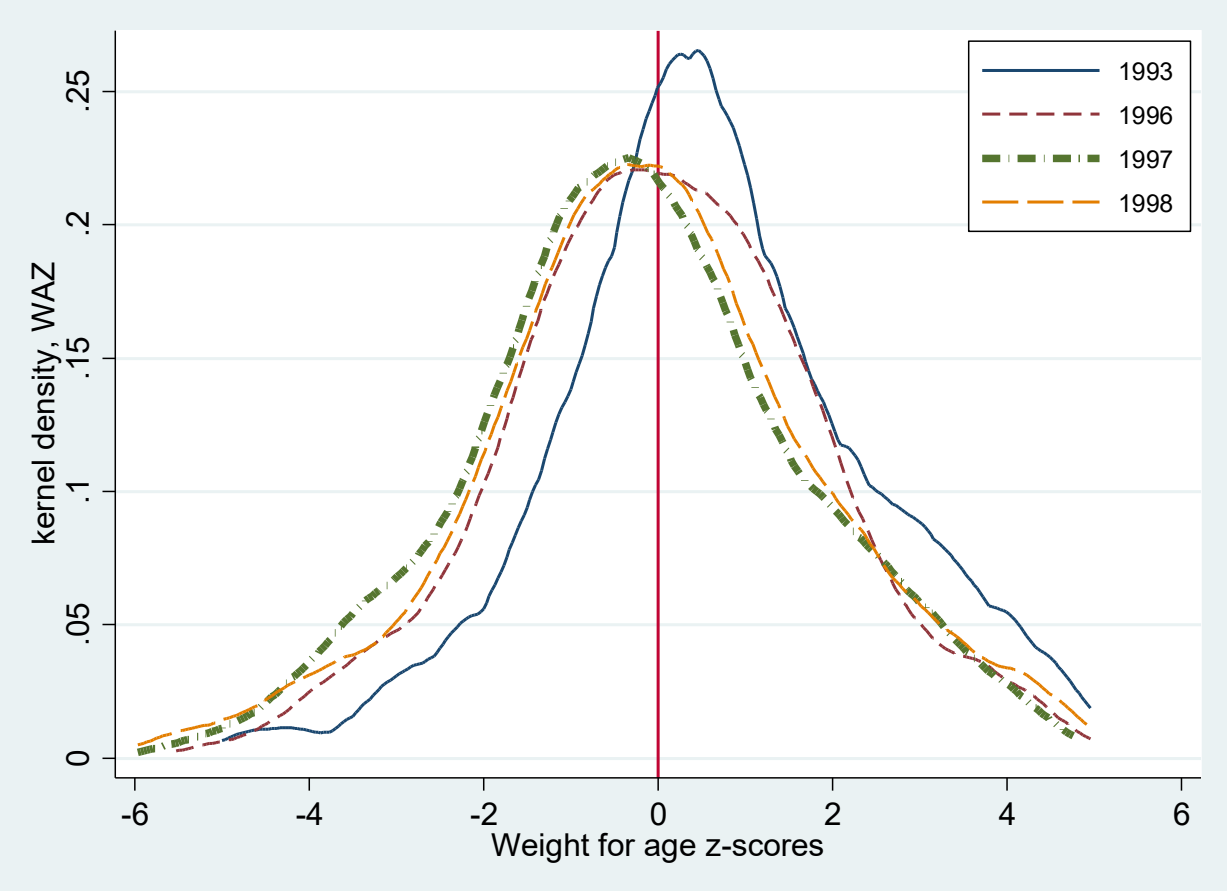

Notes: As for Figure 1. Source: as for Figure 1.

Figure 4: Weight for height z-scores (WHZ)

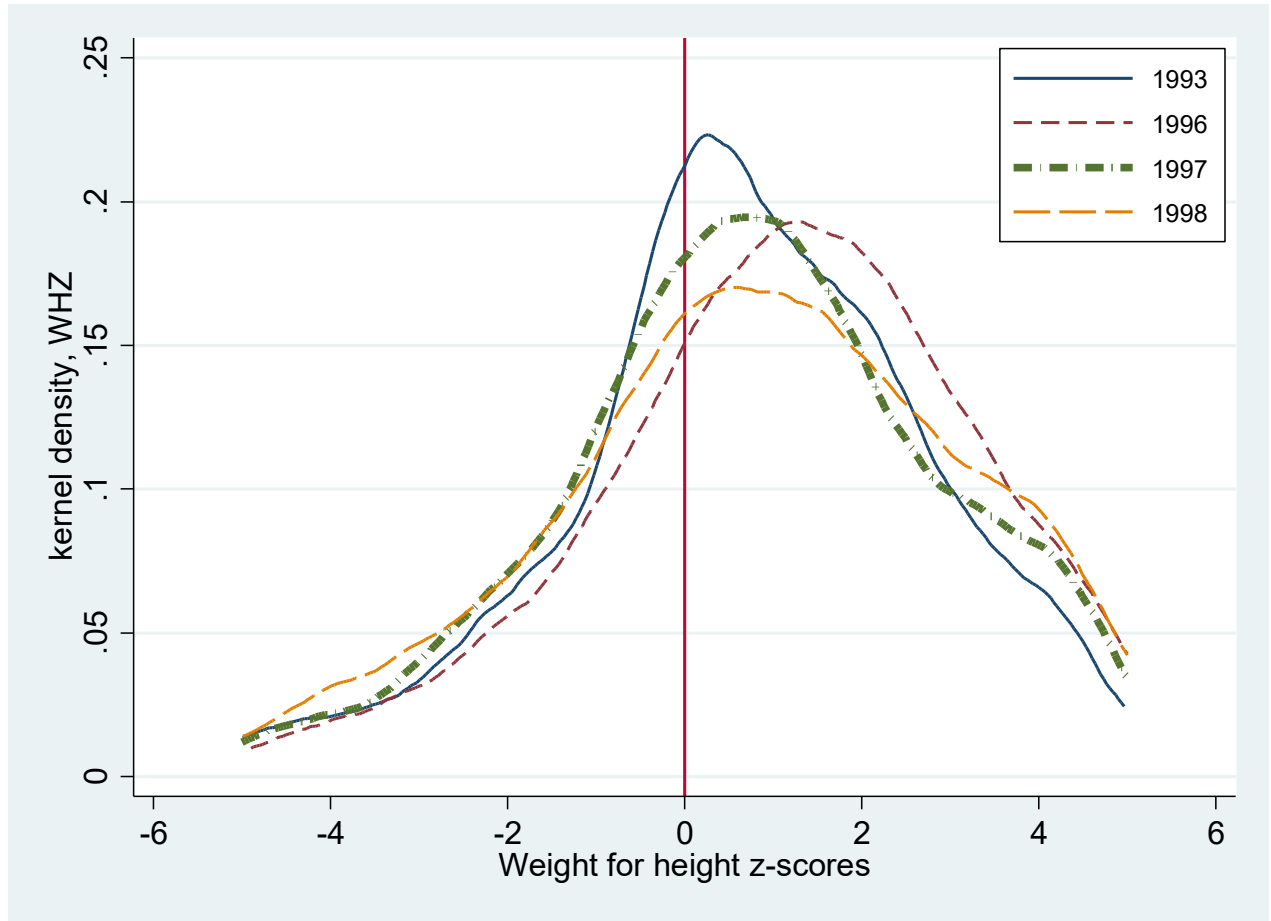

Notes: As for Figure 1. Source: as for Figure 1. 


\section{Empirical specification}

To estimate the effects of land privatization on child health and nutrition outcomes, we examine the effect of a variable indicating the number of months of a child's life (inclusive of the nine month in utero period) that they were exposed to a regime of privatized land. For all children interviewed in 1993 - with the exception of children in Naryn oblast, where privatization occurred in late 1992 - exposure is zero months. For children of a given age (in months) that were interviewed in 1996, 1997, and 1998, the extent of their exposure is determined by the oblast - survey year in which they were observed. As older children will, on average, be mechanically exposed for more months, we importantly include fixed effects for child age in months in all specifications (60 dummies in total, for the child being age 0 months (reference) through age 60 months). These capture all factors related to a child's age that should affect both health and nutrition outcomes in addition to months of exposure. Our main empirical specification, which we estimate using ordinary least squares (OLS), is as follows:

$$
Y_{i a h j t}=\beta_{0}+\beta_{1} P_{i a h j t}+\beta_{2} X_{h j t}+\delta_{a}+\alpha_{j}+\gamma_{t}+\varepsilon_{i a h j t}
$$

where $Y_{\text {ihjt }}$ is a health and nutrition outcome variable for child $i$ whose age in months is $a$ from household $h$ living in oblast $j$ in year $t$. $P_{\text {iahjt }}$ is a variable capturing the number of months of a child's life that they have been exposed to land privatization; its range is from 0 to the child's age in months plus nine (i.e. from no exposure at all to exposure for the child's entire life plus the full in utero period). $\delta_{a}$ are child age in months fixed effects, $\alpha_{j}$ are oblast fixed effects, and $\gamma_{t}$ are survey year fixed effects. $X_{h j t}$ are household head controls including age, gender, a dummy for being married, and ethnicity (Russian, Kyrgyz, Uzbek, and "other" as the base group). $t$ is either 1993, 1996, 1997, or 1998, according to the survey round. To account for correlation within birth year cohorts, we cluster standard errors at the birth year level. This specification is similar to that used by Hidrobo (2014) to study the effects of Ecuador's 1999 economic crisis on child health.

Effectively, our econometric specification means that we compare children of the same age (in months) with differential exposures to land privatization due to the timing of its roll-out. The fact that we have four rounds of data, both before and after the reform, in addition to spatial variation in the timing of privatization allows us to include not only age in months fixed effects 
but also region (oblast) and survey year fixed effects, to account for both time-invariant features of each oblast as well as political and economic changes associated with the transition that affected the entire country.

\section{5. $\underline{\text { Results }}$}

\subsection{Overall effects on child anthropometrics}

Table 4 presents OLS results from estimation of equation (1), where our outcomes are our three measures of child health and nutrition: the child's height-for-age $\mathrm{z}$-score (columns $1-3$, a measure of stunting and of long-term health and nutritional experience), weight-for-height zscore (columns $4-6$, a measure of wasting), and weight-for-age z-score (columns 7 - 9, another measure of long-term health and nutritional experience) (WHO 1997). We find that greater exposure to land privatization leads children to be both taller and heavier, increasing both measures of the child's long-term health and nutritional experience. It does not, however, affect the prevalence of wasting (low weight-for-height z-scores) — at least for the full sample of children aged $0-5$.

Increases in height appear to be predominately driven by young children under the age of two; effects on children aged 25-60 months are more than an order of magnitude smaller and statistically insignificant. The findings suggest that there are long-term positive effects of land privatization for young children's health, and that children under age two are the most affected. Considering HAZ, we estimate that for each additional month of exposure to land privatization during the life of a child aged $0-5$ (inclusive of the in utero period), their HAZ is 0.029 standard deviations lower (column 1). For comparison, Minoiu and Shemyakina (2014) estimate that in utero or early childhood exposure to the 2002 - 2007 civil conflict in Côte d'Ivoire led HAZs of children in conflict zones to be 0.414 S.D. lower than those of children born during the same period who lived outside conflict regions. These values suggest large long-term health and nutrition improvements owing to land privatization; an additional 14 months of exposure is equivalent to avoiding exposure to a conflict zone. 
Table 4: Effect of exposure to land privatization on child anthropometrics

\begin{tabular}{|c|c|c|c|c|c|c|c|c|c|}
\hline & \multicolumn{3}{|c|}{ Panel A: height for age z-scores } & \multicolumn{3}{|c|}{ Panel B: weight for age z-scores } & \multicolumn{3}{|c|}{ Panel C: weight for height z-scores } \\
\hline & All & $0-24 \mathrm{~m}$ & $25-60 \mathrm{~m}$ & All & $0-24 \mathrm{~m}$ & $25-60 \mathrm{~m}$ & All & $0-24 \mathrm{~m}$ & $25-60 \mathrm{~m}$ \\
\hline & (1) & $(2)$ & (3) & (4) & $(5)$ & (6) & (7) & $(8)$ & (9) \\
\hline $\begin{array}{l}\text { Months exposed overall } \\
\text { (including in utero period) }\end{array}$ & $\begin{array}{c}0.029 * * * \\
(0.007)\end{array}$ & $\begin{array}{l}0.111 * \\
(0.046)\end{array}$ & $\begin{array}{c}0.006 \\
(0.011)\end{array}$ & $\begin{array}{c}0.026^{* * *} \\
(0.008)\end{array}$ & $\begin{array}{l}0.070 * * \\
(0.023)\end{array}$ & $\begin{array}{c}0.002 \\
(0.007)\end{array}$ & $\begin{array}{c}0.011 \\
(0.008)\end{array}$ & $\begin{array}{c}-0.01 \\
(0.028)\end{array}$ & $\begin{array}{l}0.019^{*} \\
(0.010)\end{array}$ \\
\hline Child is female & $\begin{array}{l}0.190 * \\
(0.094)\end{array}$ & $\begin{array}{l}0.490^{*} \\
(0.210)\end{array}$ & $\begin{array}{c}0.062 \\
(0.059)\end{array}$ & $\begin{array}{c}0.042 \\
(0.075)\end{array}$ & $\begin{array}{l}0.199 * \\
(0.082)\end{array}$ & $\begin{array}{c}0.004 \\
(0.086)\end{array}$ & $\begin{array}{l}-0.073 \\
(0.060)\end{array}$ & $\begin{array}{l}-0.011 \\
(0.131)\end{array}$ & $\begin{array}{l}-0.077 \\
(0.065)\end{array}$ \\
\hline Survey 1993 & ref. & ref. & ref. & ref. & ref. & ref. & ref. & ref. & ref. \\
\hline Survey 1996 & $\begin{array}{c}-1.766^{* * *} \\
(0.166)\end{array}$ & $\begin{array}{c}-3.801 * * * \\
(0.789)\end{array}$ & $\begin{array}{l}-0.965 * * \\
(0.398)\end{array}$ & $\begin{array}{c}-1.351 * * * \\
(0.228)\end{array}$ & $\begin{array}{c}-2.575^{* * *} \\
(0.583)\end{array}$ & $\begin{array}{l}-0.501 * \\
(0.231)\end{array}$ & $\begin{array}{l}-0.125 \\
(0.277)\end{array}$ & $\begin{array}{c}0.148 \\
(0.875)\end{array}$ & $\begin{array}{l}-0.284 \\
(0.316)\end{array}$ \\
\hline Survey 1997 & $\begin{array}{c}-2.263^{* * *} \\
(0.222)\end{array}$ & $\begin{array}{c}-4.374 * * * \\
(0.836)\end{array}$ & $\begin{array}{c}-1.148 * * \\
(0.464)\end{array}$ & $\begin{array}{c}-1.794 * * * \\
(0.273)\end{array}$ & $\begin{array}{c}-3.215^{* * *} \\
(0.599)\end{array}$ & $\begin{array}{l}-0.602 * \\
(0.277)\end{array}$ & $\begin{array}{c}-0.626 \\
(0.349)\end{array}$ & $\begin{array}{l}-0.095 \\
(0.869)\end{array}$ & $\begin{array}{c}-0.989 * * \\
(0.378)\end{array}$ \\
\hline Survey 1998 & $\begin{array}{c}-2.206^{* * *} \\
(0.261)\end{array}$ & $\begin{array}{c}-4.399 * * * \\
(0.864)\end{array}$ & $\begin{array}{l}-0.936 \\
(0.546) \\
\end{array}$ & $\begin{array}{c}-1.741 * * * \\
(0.331)\end{array}$ & $\begin{array}{c}-3.138^{* * *} \\
(0.603) \\
\end{array}$ & $\begin{array}{l}-0.397 \\
(0.319) \\
\end{array}$ & $\begin{array}{c}-0.608 \\
(0.354) \\
\end{array}$ & $\begin{array}{c}-0.053 \\
(0.878) \\
\end{array}$ & $\begin{array}{c}-1.028 * \\
(0.444) \\
\end{array}$ \\
\hline $\mathrm{N}$ & 3315 & 1025 & 2290 & 3799 & 1200 & 2599 & 3050 & 994 & 2056 \\
\hline R squared & 0.12 & 0.21 & 0.08 & 0.07 & 0.11 & 0.05 & 0.04 & 0.04 & 0.04 \\
\hline
\end{tabular}

Source: World Bank LSMS (1993, 1996, 1997 and 1998). The date of land reform (to calculate months a child was "exposed" to reform) is based on 2016 Life in Kyrgyzstan survey (which provided the month and year).

Notes: These are OLS regressions. "All”, "0-24m" and "25-60m" - the sub-sample includes children aged 0-60, "0-24" and "25-60" months old, respectively, at the time of the survey. The regressions are estimated for the sample of children who live in rural areas. "Months exposed overall (including in utero period)" is the number of months a child was alive during the land reform plus months exposed to land reform in utero. All regressions include survey year fixed effects, oblast fixed effects, child age in months fixed effects, and controls for household head: age, gender, a dummy for being married; and ethnicity (Russian, Kyrgyz, Uzbek, with "other" being a reference group.) Standard errors are clustered at the year of child birth level and appear in parentheses. $* \mathrm{p}<0.10, * * \mathrm{p}<0.05, * * *$ $\mathrm{p}<0.01$. 
The effects are even larger among younger children. For children aged $0-24$ months, the effect is a 0.111 standard deviations decrease in their HAZ (column 2). In contrast, for children aged $25-60$ months, there is not a statistically significant effect of land privatization exposure on HAZs, and furthermore, the point estimate itself is appreciably smaller, at 0.006 (column 3). This effect is consistent with children being especially vulnerable to investments in their health earlier in their lives.

Next considering children's WAZs as our outcome, we find that an additional month of exposure to land privatization lowers the WAZ of $0-5$ year olds by 0.026 standard deviations (column 4), and it lowers the WAZ of $0-24$ month olds by an even more sizeable 0.07 standard deviations (column 5). Similar to the case of the HAZ, exposure to land privatization does not appear to affect the WAZs of 25 - 60 month olds; the coefficient is a mere 0.002 , and the effect is furthermore statistically insignificant (column 6).

Only for $25-60$ month olds (and not $0-5$ year olds overall, nor for the subset of $0-24$ month olds) does exposure to land privatization appears to affect WHZs (columns 7 -9). Furthermore, the effect size is also more modest than the statistically significant effects estimated for the case of the HAZ and WAZ, at only 0.019 standard deviations (column 9). Overall, we take this finding as evidence that exposure to land privatization has positive impacts on the longterm health and nutrition of $0-5$ year olds, predominately driven by effects on $0-24$ month olds, and possibly some effects on decline in malnutrition among children aged $24-60$ months old.

Similar results hold when we drop 1993 and use only data from the three latter surveys, as shown in Appendix Table A2. Among 0 - 5 year olds, while the coefficient on months of exposure in the HAZ and WAZ regressions grows slightly smaller in magnitude and statistical significance, our broad conclusions remain: increased exposure to land privatization is associated with overall gains in long-term health and nutrition, driven predominately by $0-24$ month olds. This finding is of significance given that the precision of our information on exact child age is smallest for this earliest survey wave. While our power is decreased by dropping one of the four survey waves, our main conclusions hold.

The results are also not particularly sensitive to the control set used. In Appendix Table A3, we drop our household head controls and obtain nearly identical point estimates to those found in Table 4-differing only in the third decimal point and only for some specifications. 
Also, all of the coefficients that were statistically significant at conventional levels in Table 4 remain so here as well. In Appendix Table A4, we further check robustness of the results to controlling for household land access (a dummy) as well as the number of hectares of land in the household's possession. Once again, the point estimates on months of exposure and their levels of statistical significance are preserved for both the HAZ (columns 1-3) and WAZ (columns 4 - 6) outcomes, and for all sub-samples (ages 0-5, 0-24 months, and 25-60 months). That the results are not particularly sensitive to observable controls also increases our confidence that they are not simply explained by un-observables in the error term that affect both privatization exposure and health and nutrition outcomes. They may also suggest that increasing access to land is not the main channel explaining child health improvements - though we caveat this analysis by noting that access to land is likely endogenous to these same child health outcomes.

Results are also robust to transforming the independent variable of interest. In Appendix Table A5, we log exposure to land reform, in months, to allow a non-linear relationship in which each additional month may not have a constant effect on child health. This specification is nonideal given that many children have zero months of exposure; in these cases, we impute exposure as 0.001 months. We see that greater exposure to land privatization continues to predict statistically significantly better HAZ and WAZ outcomes in children aged $0-5$, with point estimates in both cases larger for very young children ( $0-24$ months old $)$ compared to older children.

We next consider whether the results are sensitive to our assumptions about the speed with which land privatization's impacts were realized by perturbing the timing of privatization, in Appendix Table A6. Taking health outcomes of children aged $0-5$ as our outcome, Panel A perturbs the timing of land privatization one year forward in time, which assumes a delayed effect of the reform (i.e., a lagged response). Panel B, in contrast, moves it one year backward in time, which assumes that there are anticipatory effects of the reform. This set-up might be the case if individuals knew that the reform was coming and were able to seize land plots and manage them privately before it was widely recognized that land had been privatized. There are strong reasons to think anticipatory effects would hold given that an initial wave of land reform 
started in late 1991 - early 1992 and was then tabled in March of 1992 due to concerns about unfairness in land distribution and high input prices for farmers (World Bank 1993). ${ }^{11}$

Whether we perturb the timing of land privatization forward or backward by one year, a greater number of months of exposure to land privatization leads to statistically significantly higher HAZ and WAZ values among $0-5$ year olds. While length of exposure to land privatization is in both cases positively correlated with WHZ values, this relationship is only statistically significant when allowing for anticipatory effects (i.e., moving the date of reform backward by one year). Panel A, column 1 considers the HAZ; the point estimate on months of exposure for the 0 - 5 sample is slightly smaller than its Table 4 counterpart. In contrast, in Panel $\mathrm{B}$, the comparable point estimate (also column 1) becomes larger than its Table 4 counterpart. For the other two outcomes as well, WAZ and WHZ, the anticipatory effects of the reform are stronger than the lagged ones, in both magnitude and statistical significance. We conclude that whether the reform took time to have an effect or started having an effect even before it became official policy, there is a strong evidence that it benefited long-term child health and nutrition. Further, that estimates are larger and more statistically significant when we allow anticipatory effects may suggest that reform indeed began to change land management before it was officially recognized as doing so.

5.2 Heterogeneous effects on child anthropometrics by gender and poverty

We next examined if the effects in Table 4 varied by gender (Table 5). On the one hand, there may be difference in resilience to shocks in general across genders. Additionally, households may respond to a shock like land privatization with compensatory behavior that may tend to affect boy and girl children in different ways; for example, if land privatization softened households' budget constraints and increased food consumption, girls might benefit most if boys had been prioritized previously. However, we find no evidence that the effects of our exposure variable varies by gender. For both our HAZ and WAZ outcomes, the interaction effect between

\footnotetext{
11 This scenario is highly plausible given that the initial wave of reform started in late 1991 - early 1992 and was tabled in March of 1992 due to concerns about unfairness in land distribution and high input prices for farmers (World Bank 1993).
} 
exposure and a dummy for being female is small in magnitude and furthermore statistically insignificant.

Table 5: Effect of exposure to land privatization on child anthropometrics, by gender

\begin{tabular}{lcccccc}
\hline & \multicolumn{2}{c}{ Panel A: height for age z-scores } & \multicolumn{2}{c}{ Panel B: weight for age z-scores } \\
\cline { 2 - 7 } & All & $0-24 \mathrm{~m}$ & $25-60 \mathrm{~m}$ & All & $0-24 \mathrm{~m}$ & $25-60 \mathrm{~m}$ \\
\hline & $(1)$ & $(2)$ & $(3)$ & $(4)$ & $(5)$ & $(6)$ \\
Months exposed overall (including in & $0.030^{* * *}$ & $0.112^{* *}$ & 0.003 & $0.026^{* *}$ & $0.072^{* *}$ & 0.000 \\
utero period) & $(0.007)$ & $(0.042)$ & $(0.010)$ & $(0.008)$ & $(0.023)$ & $(0.009)$ \\
Child is female & 0.236 & $0.507^{* *}$ & -0.062 & 0.044 & 0.283 & -0.079 \\
& $(0.201)$ & $(0.187)$ & $(0.154)$ & $(0.145)$ & $(0.281)$ & $(0.226)$ \\
Exposed * Female & -0.002 & -0.001 & 0.004 & 0.000 & -0.004 & 0.003 \\
& $(0.004)$ & $(0.012)$ & $(0.003)$ & $(0.004)$ & $(0.012)$ & $(0.005)$ \\
Survey 1993 & ref. & ref. & ref. & ref. & ref. & ref. \\
Survey 1996 & $-1.768^{* * *}$ & $-3.800^{* * *}$ & $-0.953^{* *}$ & $-1.351^{* * *}$ & $-2.571^{* * *}$ & $-0.486^{*}$ \\
& $(0.165)$ & $(0.801)$ & $(0.373)$ & $(0.230)$ & $(0.586)$ & $(0.229)$ \\
Survey 1997 & $-2.265^{* * *}$ & $-4.373^{* * *}$ & $-1.111^{* *}$ & $-1.794^{* * *}$ & $-3.211^{* * *}$ & $-0.568^{*}$ \\
& $(0.222)$ & $(0.849)$ & $(0.409)$ & $(0.275)$ & $(0.601)$ & $(0.285)$ \\
Survey 1998 & $-2.208^{* * *}$ & $-4.398^{* * *}$ & -0.875 & $-1.741^{* * *}$ & $-3.134 * * *$ & -0.378 \\
& $(0.260)$ & $(0.876)$ & $(0.474)$ & $(0.333)$ & $(0.606)$ & $(0.321)$ \\
Age in months FE & Yes & Yes & Yes & Yes & Yes & Yes \\
Oblast FE & Yes & Yes & Yes & Yes & Yes & Yes \\
HH Head controls & Yes & Yes & Yes & Yes & Yes & Yes \\
\hline $\mathrm{N}$ & 3315 & 1025 & 2234 & 3799 & 1200 & 2534 \\
$\mathrm{R}$ squared & 0.12 & 0.21 & 0.08 & 0.07 & 0.11 & 0.05 \\
\hline
\end{tabular}

Source: World Bank LSMS (1993, 1996, 1997 and 1998) and Life In Kyrgyzstan Study (2016).

Notes: These are OLS regressions using the sample of children aged 0-60 months old at the time of the survey. "All", "0-24m" and "25-60m" refer to children aged 0-60, 0-24, and 25-60 months old, respectively, at the time of the survey. The regressions are estimated for the sub-sample of children living in rural areas. "Months exposed overall (including in utero period)" or "Exposed" is the number of months a child was alive (including the in utero period) while land privatization was in place. The date of land reform (to calculate months of exposure) is based on the 2016 Life in Kyrgyzstan Study (which provided the month and year). Standard errors are clustered at the year of child birth level and appear in parentheses. ${ }^{*} \mathrm{p}<0.10,{ }^{* *} \mathrm{p}<0.05, * * * \mathrm{p}<0.01$.

Next, we considered whether relatively poor or relatively less-poor households tended to benefit most by considering whether an interaction term between the household having median or below household expenditure and months of exposure to land privatization is statistically significant (Table 6). It is important to note that the Kyrgyz Republic was a low-income country in the 1990s (and indeed up until 2014) and child HAZ and WAZ were actively declining. With 75 percent of the population living in rural areas and with two-thirds of rural residents being below poverty line (World Bank 1998), above-median households should not be thought of as 
rich; they are simply households capable of productively using a small plot of land such that the land access could actually benefit child health. As Table 6 shows, young children aged $0 \_5$ similarly benefited from exposure to land privatization, whether they lived in above- or belowmedian expenditure households. However, among more vulnerable $0-24$ month olds, it is in fact the less-poor households that tended to see greater gains from land privatization for their very young children, in the form of higher HAZ and WAZ scores. This finding supports a story in which access to land which land privatization conferred could only help very young children whose parents had a sufficiently high level of income for rural Kyrgyzstan - possibly as this minimum amount of income permitted households to purchase the inputs necessary to make efficient use of their new land, or possibly because it permitted households to make other investments in their children that were complementary to those that greater access to land afforded them. Another possibility is that better quality land went to higher-income and thus more influential individuals, allowing them to earn more from this (more productive) land. While we lack data on land quality, sub-section 5.2 helps us better understand the mechanisms likely driving child health improvements by considering how land privatization affected land access, and additionally how these effects varied according to household income (specifically, whether it was above median or not). 
Table 6: Effect of exposure to land privatization on child anthropometrics, by household having expenditure at median or below

\begin{tabular}{|c|c|c|c|c|c|c|c|c|c|}
\hline & \multicolumn{3}{|c|}{ Panel A: height for age z-scores } & \multicolumn{3}{|c|}{ Panel B: weight for age z-scores } & \multicolumn{3}{|c|}{ Panel C: weight for height z-scores } \\
\hline & All & $0-24 \mathrm{~m}$ & $25-60 \mathrm{~m}$ & All & $0-24 \mathrm{~m}$ & $25-60 \mathrm{~m}$ & All & $0-24 \mathrm{~m}$ & $25-60 \mathrm{~m}$ \\
\hline \multirow{3}{*}{$\begin{array}{l}\text { Months exposed overall } \\
\text { (including in utero period) }\end{array}$} & (1) & (2) & (3) & (4) & (5) & (6) & (7) & (8) & (9) \\
\hline & $0.034 * * *$ & $0.123^{* *}$ & 0.011 & $0.029 * * *$ & $0.081^{* *}$ & 0.005 & 0.011 & -0.015 & $0.020^{*}$ \\
\hline & $(0.007)$ & $(0.048)$ & $(0.012)$ & $(0.008)$ & $(0.025)$ & $(0.007)$ & $(0.007)$ & $(0.028)$ & $(0.010)$ \\
\hline \multirow[t]{2}{*}{ Child is female } & $0.190^{*}$ & $0.503 *$ & 0.065 & 0.043 & $0.205^{*}$ & 0.007 & -0.073 & -0.005 & -0.076 \\
\hline & $(0.095)$ & $(0.210)$ & $(0.056)$ & $(0.075)$ & $(0.084)$ & $(0.085)$ & $(0.060)$ & $(0.134)$ & $(0.065)$ \\
\hline Survey 1993 & ref. & ref. & ref. & ref. & ref. & ref. & ref. & ref. & ref. \\
\hline \multirow[t]{2}{*}{ Survey 1996} & $-1.760 * * *$ & $-3.720 * * *$ & $-0.953 * *$ & $-1.351 * * *$ & $-2.537 * * *$ & $-0.497^{*}$ & -0.125 & 0.116 & -0.284 \\
\hline & $(0.165)$ & $(0.804)$ & $(0.392)$ & $(0.227)$ & $(0.589)$ & $(0.233)$ & $(0.277)$ & $(0.880)$ & $(0.315)$ \\
\hline \multirow[t]{2}{*}{ Survey 1997} & $-2.253 * * *$ & $-4.313 * * *$ & $-1.137 * *$ & $-1.793 * * *$ & $-3.179 * * *$ & $-0.600^{*}$ & -0.626 & -0.125 & $-0.990 * *$ \\
\hline & $(0.222)$ & $(0.847)$ & $(0.457)$ & $(0.273)$ & $(0.603)$ & $(0.280)$ & $(0.348)$ & $(0.873)$ & $(0.375)$ \\
\hline \multirow[t]{2}{*}{ Survey 1998} & $-2.201 * * *$ & $-4.297 * * *$ & -0.932 & $-1.742 * * *$ & $-3.100 * * *$ & -0.397 & -0.608 & -0.079 & $-1.030^{*}$ \\
\hline & $(0.259)$ & $(0.881)$ & $(0.539)$ & $(0.332)$ & $(0.610)$ & $(0.320)$ & $(0.351)$ & $(0.880)$ & $(0.445)$ \\
\hline \multirow{2}{*}{$\begin{array}{l}\text { Exposed*Below or equal to median } \\
\text { expenditure }(=1)\end{array}$} & -0.01 & $-0.039 * * *$ & -0.01 & -0.006 & $-0.029 * *$ & -0.006 & 0.001 & 0.014 & -0.002 \\
\hline & $(0.005)$ & $(0.010)$ & $(0.006)$ & $(0.004)$ & $(0.011)$ & $(0.004)$ & $(0.003)$ & $(0.011)$ & $(0.004)$ \\
\hline \multirow{2}{*}{$\begin{array}{l}\text { Indicator for Total Expenditure below } \\
\text { or equal to median expenditure } \\
\text { (deflated) }\end{array}$} & 0.148 & 0.314 & 0.321 & 0.156 & 0.398 & 0.233 & -0.021 & -0.339 & 0.091 \\
\hline & $(0.195)$ & $(0.201)$ & $(0.242)$ & $(0.106)$ & $(0.222)$ & $(0.144)$ & $(0.141)$ & $(0.240)$ & $(0.112)$ \\
\hline $\mathrm{N}$ & 3315 & 1025 & 2290 & 3799 & 1200 & 2599 & 3050 & 994 & 2056 \\
\hline $\mathrm{R}$ squared & 0.12 & 0.22 & 0.08 & 0.07 & 0.12 & 0.05 & 0.04 & 0.04 & 0.05 \\
\hline
\end{tabular}

Source: World Bank LSMS (1993, 1996, 1997 and 1998). The date of land reform (to calculate months a child was "exposed" to reform) is based on 2016 Life in Kyrgyzstan survey (which provided the month and year).

Notes: These are OLS regressions. "All", "0-24m" and " $25-60 \mathrm{~m}$ " - the sub-sample includes children aged 0-60, "0-24" and " $25-60$ " months old, respectively, at the time of the survey. The regressions are estimated for the sample of children who live in rural areas. "Months exposed overall (including in utero period)"or "Exposed" is the number of months a child was alive during the land reform plus months exposed to land reform in utero. All regressions include survey year fixed effects, oblast fixed effects, child age in months fixed effects, and controls for household head: age, gender, a dummy for being married; and ethnicity (Russian, Kyrgyz, Uzbek, with "other" being a reference group.) Standard errors are clustered at the year of child birth level and appear in parentheses. * $<<0.10$, $* * \mathrm{p}<0.05, * * * \mathrm{p}<0.01$. 


\subsection{Mechanisms}

To explore the mechanisms driving our results, we next estimated household-level regressions of consumption-related outcomes as well as land access related outcomes on months of exposure to land privatization. In these regressions, months of exposure is an average level of exposure that varies at the oblast - year level (and is thus common for all households surveyed in the same oblast in the same year). The consumption outcomes include monthly food purchases, monthly value of food produced and consumed at home, total food expenditures (the sum of the previous two amounts), total monthly non-food expenditures, and total overall expenditures (the sum of the previous two amounts). The land access outcomes include a dummy for land access and the number of hectares of land the household has. The results for both sets of outcomes appear in Table 7.

We see that land reform increased households' total consumption, but not due to increased purchases of food in the market. Instead, food produced at home and consumed increased substantially. For each month of additional exposure to land privatization, households increased their consumption of home produced food, crops and animal products, by about 155.1 soms per month (measured in constant, 1995 soms). This is a sizeable increase that explains similarly sizeable child health improvements. In contrast, we find no statistically significant increases in non-food expenditures.

Exposure to land reform also increased access to land on both the extensive and the intensive margins, with an additional month of exposure leading to a 1.5 percentage point increase in the likelihood of reporting having access to land, and a 0.1 hectare increase in the

amount of land accessed. This observation points towards the source of consumption gains from home production: individuals are more likely to have land to farm, and they have more of it, expanding their production possibilities. 
Table 7: Effect of exposure to land privatization on land access and monthly food production and expenditures

\begin{tabular}{|c|c|c|c|c|c|c|c|}
\hline & \multicolumn{2}{|c|}{$\begin{array}{c}\text { Panel A: Land access } \\
\text { variables }\end{array}$} & \multicolumn{5}{|c|}{ Panel B: household monthly expenditure } \\
\hline & $\mathrm{HH}$ has land & $\begin{array}{c}\text { Hectares of } \\
\text { land } \mathrm{HH} \text { has } \\
\text { access to }\end{array}$ & $\begin{array}{c}\text { Food } \\
\text { purchases }\end{array}$ & $\begin{array}{c}\text { Food home } \\
\text { produced \& } \\
\text { consumed }\end{array}$ & $\begin{array}{c}\text { Total value of } \\
\text { food } \\
\text { consumption } \\
(3)+(4)\end{array}$ & $\begin{array}{c}\text { Nonfood } \\
\text { expenditures }\end{array}$ & $\begin{array}{c}\text { Total food } \\
\text { and non-food } \\
\text { expenditure: } \\
(5)+(6)\end{array}$ \\
\hline & $(1)$ & $(2)$ & (3) & (4) & $(5)$ & $(6)$ & $(7)$ \\
\hline Average months exposed & $\begin{array}{c}0.015^{* * *} \\
(0.003)\end{array}$ & $\begin{array}{c}0.100 * * * \\
(0.034)\end{array}$ & $\begin{array}{c}10.9 \\
(14.9)\end{array}$ & $\begin{array}{c}155.1^{* * *} \\
(33.2)\end{array}$ & $\begin{array}{c}166.0 * * * \\
(36.3)\end{array}$ & $\begin{array}{l}-22.7 \\
(20.1)\end{array}$ & $\begin{array}{c}143.4^{* * *} \\
(42.6)\end{array}$ \\
\hline HH size & $\begin{array}{c}0.016 * * * \\
(0.002)\end{array}$ & $\begin{array}{c}0.142 * * * \\
(0.035)\end{array}$ & $\begin{array}{c}67.2^{* * *} \\
(14.1)\end{array}$ & $\begin{array}{c}108.4 * * * \\
(23.4)\end{array}$ & $\begin{array}{c}175.5 * * * \\
(27.8)\end{array}$ & $\begin{array}{c}47.0 * * \\
(21.2)\end{array}$ & $\begin{array}{c}222.5^{* * * *} \\
(35.1)\end{array}$ \\
\hline Constant & $\begin{array}{c}0.689 * * * \\
(0.032)\end{array}$ & $\begin{array}{l}-0.991 \\
(0.612) \\
\end{array}$ & $\begin{array}{c}1,104.3^{* * *} \\
(108.9)\end{array}$ & $\begin{array}{c}3,184.9 * * * \\
(433.2)\end{array}$ & $\begin{array}{c}4,289.2^{* * *} \\
(442.4)\end{array}$ & $\begin{array}{l}722.7^{*} \\
(426.1) \\
\end{array}$ & $\begin{array}{c}5,011.9 * * * \\
(617.2)\end{array}$ \\
\hline N obs & 6,000 & 5,991 & 6,024 & 6,024 & 6,024 & 6,024 & 6,024 \\
\hline R-squared & 0.111 & 0.028 & 0.156 & 0.055 & 0.087 & 0.007 & 0.077 \\
\hline
\end{tabular}

Source: World Bank LSMS (1993, 1996, 1997, and 1998) and Life in Kyrgyzstan Study (2016).

Notes: These are household-level OLS regressions estimated using all rural households. "Average months exposed" is an average level of exposure that varies at the oblast - year level (and is thus common for all households surveyed in the same oblast in the same year). Expenditure on food and total expenditure numbers are in Kyrgyz som and deflated using World Bank GDP deflator data for Kyrgyzstan, with base year 1995.

(https://data.worldbank.org/indicator/NY.GDP.DEFL.ZS, last accessed: July 28, 2018). Non-food expenditure includes: expenditure on frequent non-food purchases; infrequent non-food purchases; consumption of durable goods, and expenditure on utilities. All expenditures are converted on the 30 day basis using method outlined in World Bank (2002). The date of land reform is based on the 2016 Life in Kyrgyzstan Study (which provided the month and year). All regressions include survey year fixed effects, oblast fixed effects, child age in months fixed effects, and controls for household head: age, gender, a dummy for being married; and ethnicity (Russian, Kyrgyz, Uzbek, with "other" being a reference group.) Robust standard errors clustered at the household level appear in parentheses. $* \mathrm{p}<0.10, * * \mathrm{p}<0.05, * * * \mathrm{p}<0.01$ 
We next considered how the effects of land privatization on access to land (on both the extensive and intensive margins) vary with the household's socio-economic status, as measured by the household having total expenditure below the median. These results appear in Table 8; from column 1, we find some limited evidence that households with below-median total expenditures were statistically significantly more likely to acquire land than were their less-poor counterparts, but the difference is economically very small: for less-poor households, an additional month of exposure to land privatization increases their probability of having access to private land by 1.4 percentage points, while the effect for the poorest half of households is 1.6. While these are statistically different, the difference is small. Further, we find no evidence that exposure to land privatization differentially affects the poor and the less-poor in terms of total hectares of land that they access. Overall, we find little evidence that households with higher income were better able to access land during the privatization reform, suggesting that greater health gains among the less poor may be due to the inputs they had to make land productive rather than their greater ability to access land in the first place.. 
Table 8: Heterogeneous effects of exposure to land privatization on land access by household socio-economic status

\begin{tabular}{lcc}
\hline VARIABLES & $\begin{array}{c}\text { HH has } \\
\text { land, } \\
\text { indicator }\end{array}$ & $\begin{array}{c}\text { Hectares of } \\
\text { land HH } \\
\text { has access } \\
\text { to }\end{array}$ \\
\hline Average months exposed & $(1)$ & $(2)$ \\
HH Size & $0.014^{* * *}$ & $0.100^{* * *}$ \\
& $(0.003)$ & $(0.032)$ \\
Exposed * Below or equal to & $0.012^{* * *}$ & $0.107^{* * *}$ \\
median expenditure $(=1)$ & $(0.002)$ & $(0.034)$ \\
Indicator for Total Expenditure & $0.002^{* * *}$ & 0.002 \\
below or equal to median & $(0.000)$ & $(0.006)$ \\
expenditure (deflated) & $-0.172^{* * *}$ & $-0.684^{* *}$ \\
Constant & $(0.021)$ & $(0.302)$ \\
& $0.800^{* * *}$ & -0.418 \\
Observations & $(0.033)$ & $(0.670)$ \\
R-squared & 6,000 & 5,991 \\
\hline
\end{tabular}

Source: World Bank LSMS (1993, 1996, 1997, and 1998) and Life in Kyrgyzstan Study (2016).

Notes: These are household-level OLS regressions estimated using all rural households. "Average months exposed" is an average level of exposure that varies at the oblast - year level (and is thus common for all households surveyed in the same oblast in the same year). Expenditure on food and total expenditure numbers are in Kyrgyz som and deflated using World Bank GDP deflator data for Kyrgyzstan, with base year 1995.

(https://data.worldbank.org/indicator/NY.GDP.DEFL.ZS, last accessed: July 28, 2018). Non-food expenditure includes: expenditure on frequent non-food purchases; infrequent non-food purchases; consumption of durable goods, and expenditure on utilities. All expenditures are converted on the 30 day basis using method outlined in World Bank (2002). The date of land reform is based on the 2016 Life in Kyrgyzstan Study (which provided the month and year). All regressions include survey year fixed effects, oblast fixed effects, child age in months fixed effects, and controls for household head: age, gender, a dummy for being married; and ethnicity (Russian, Kyrgyz, Uzbek, with "other" being a reference group.) Robust standard errors clustered at the household level appear in parentheses. ${ }^{*} \mathrm{p}<0.10,{ }^{* *} \mathrm{p}<0.05, * * * \mathrm{p}<0.01$.

\subsection{Placebo analysis}

We next carry out a placebo analysis that considers the impact of exposure to land privatization on urban children. Urban households were not directly exposed to land privatization in the way rural households were given that they were ineligible to receive plots of land from the government. As such, urban-dwelling children were removed from all analysis up to this point. They could very well be exposed to changes in prices and other general equilibrium effects in their oblasts generated by privatization of land. However, we would expect these effects to be relatively modest.

As Table 9 shows, we indeed find that the main effects of privatization on child anthropometrics identified in Table 4 are substantially weakened when we consider urban 
children. As columns $1-3$ demonstrate, we no longer find any statistically significant effects of exposure to land privatization on HAZ values - either for 0 - 5 year olds overall, or for our two sub-groups ( 0 - 24 month olds, or 25 - 60 month olds). If anything, our exposure variable now has a negative effect on HAZ - though it is very far from being statistically significant, and the point estimates are furthermore very small (always under 0.008 ). While we identify some effects of exposure to land privatization on WAZ values of $0-5$ year olds overall, the coefficient is just over a third the size it was in our main results from Table 4, and it's statistical significance is diminished as well (while significant at the 0.01 level in Table 4, it is only significant at the 0.10 level here). Furthermore, we find no impacts on the WAZ values of $0-24$ month holds or 25 60 month olds individually, and the coefficient for $0-24$ month olds is in fact negative (though far from statistically significant at conventional levels). This observation is in contrast to a rather large coefficient on months of exposure of 0.07 (significant at the 0.05 level) in our main (Table 4) WAZ results for $0-24$ month olds. We find some evidence that $\mathrm{WHZ}$ values increase in urban children aged $0-5$ overall, but these effects are not apparent among $0-24$ month olds or among 25-60 month olds individually.

Appendix Table A7 considers whether our results for rural versus urban children are statistically significantly different by taking all children - rural children from our main analysis (Table 4) as well as urban children from Table 9-and interacting all independent variables including months of exposure with an urban dummy. We find that the effect of months of exposure on HAZ and on WAZ values is indeed statistically significantly lower for urban children. For the HAZ, the coefficient on months of exposure is 0.029 and the coefficient on months of exposure interacted with an urban dummy is -0.031 , showing that the effect of exposure is coming fully from rural children, and the effect is effectively zero for urban children. For WAZ values, there is some evidence of statistically significantly smaller but still positive impacts on urban children. For WHZ values, neither months of exposure nor its interaction with an urban dummy is statistically significant.

Overall, we conclude that the improvements in child anthropometrics are concentrated in rural areas, as we would expect given the nature of the reform - which predominately benefited rural households by granting them (and not urban households) access to privately-held land. While there is at least some evidence of urban children benefiting through higher WAZ values, the fact that these benefits are substantially muted compared to effects in rural areas provides 
evidence that they are not simply due to contemporaneous economic and policy changes that equally impacted rural and urban areas. Rather, they appear to be due to the unique features of the land privatization reform itself, which impacted rural areas predominately but may have affected urban children to a lesser degree through general equilibrium effects or other spillover benefits. 
Table 9: Effect of exposure to land privatization on child anthropometrics, placebo with urban dwelling children

\begin{tabular}{|c|c|c|c|c|c|c|c|c|c|}
\hline & \multicolumn{3}{|c|}{ Panel A: height for age z-scores } & \multicolumn{3}{|c|}{ Panel B: weight for age z-scores } & \multicolumn{3}{|c|}{ Panel C: weight for height z-scores } \\
\hline & All & $0-24 \mathrm{~m}$ & $25-60 \mathrm{~m}$ & All & $0-24 \mathrm{~m}$ & $25-60 \mathrm{~m}$ & All & $0-24 \mathrm{~m}$ & $25-60 \mathrm{~m}$ \\
\hline & (1) & $(2)$ & (3) & (4) & $(5)$ & (6) & (7) & $(8)$ & (9) \\
\hline $\begin{array}{l}\text { Months exposed overall } \\
\text { (including in utero }\end{array}$ & -0.002 & -0.006 & -0.008 & $0.010^{*}$ & -0.026 & 0.005 & $0.022 * *$ & -0.015 & 0.02 \\
\hline period) & $(0.007)$ & $(0.032)$ & $(0.008)$ & $(0.005)$ & $(0.023)$ & $(0.006)$ & $(0.007)$ & $(0.021)$ & $(0.011)$ \\
\hline \multirow[t]{2}{*}{ Child is female } & $0.379 * *$ & $0.562 *$ & 0.239 & 0.055 & 0.099 & 0.054 & -0.108 & -0.209 & -0.073 \\
\hline & $(0.162)$ & $(0.235)$ & $(0.206)$ & $(0.097)$ & $(0.299)$ & $(0.107)$ & $(0.088)$ & $(0.322)$ & $(0.119)$ \\
\hline Survey 1993 & ref. & ref. & ref. & ref. & ref. & ref. & ref. & ref. & ref. \\
\hline \multirow[t]{2}{*}{ Survey 1996} & -0.763 & $-3.341 * * *$ & -0.051 & $-0.764 * *$ & -0.261 & $-0.719 *$ & -0.115 & $1.565 * *$ & -0.482 \\
\hline & $(0.559)$ & $(0.731)$ & $(0.435)$ & $(0.318)$ & $(0.866)$ & $(0.333)$ & $(0.343)$ & $(0.482)$ & $(0.406)$ \\
\hline \multirow[t]{2}{*}{ Survey 1997} & $-1.024 *$ & $-3.602 * * *$ & -0.267 & $-0.956 * *$ & -0.797 & $-0.741 *$ & -0.132 & $1.077 * *$ & -0.319 \\
\hline & $(0.543)$ & $(0.722)$ & $(0.385)$ & $(0.310)$ & $(0.707)$ & $(0.334)$ & $(0.344)$ & $(0.399)$ & $(0.486)$ \\
\hline \multirow[t]{2}{*}{ Survey 1998} & -0.839 & $-3.289 * *$ & -0.124 & $-0.871 * *$ & -0.706 & -0.61 & -0.097 & $1.690 * * *$ & -0.529 \\
\hline & $(0.587)$ & $(0.927)$ & $(0.376)$ & $(0.358)$ & $(0.838)$ & $(0.383)$ & $(0.340)$ & $(0.379)$ & $(0.431)$ \\
\hline Age in months FE & Yes & Yes & Yes & Yes & Yes & Yes & Yes & Yes & Yes \\
\hline Oblast FE & Yes & Yes & Yes & Yes & Yes & Yes & Yes & Yes & Yes \\
\hline HH Head FE & Yes & Yes & Yes & Yes & Yes & Yes & Yes & Yes & Yes \\
\hline $\mathrm{N}$ & 988 & 340 & 648 & 1120 & 379 & 741 & 916 & 305 & 611 \\
\hline $\mathrm{R}$ squared & 0.14 & 0.23 & 0.12 & 0.14 & 0.20 & 0.08 & 0.10 & 0.19 & 0.08 \\
\hline
\end{tabular}

Source: World Bank LSMS (1993, 1996, 1997 and 1998). The date of land reform (to calculate months a child was "exposed" to reform) is based on 2016 Life in Kyrgyzstan survey (which provided the month and year).

Notes: These are OLS regressions. "All", "0-24m" and "25-60m" - the sub-sample includes children aged 0-60, "0-24" and " $25-60 "$ months old, respectively, at the time of the survey. The regressions are estimated for the sample of children who live in rural areas. "Months exposed overall (including in utero period)" is the number of months a child was alive during the land reform plus months exposed to land reform in utero. All regressions include survey year fixed effects, oblast fixed effects, child age in months fixed effects, and controls for household head: age, gender, a dummy for being married; and ethnicity (Russian, Kyrgyz, Uzbek, with "other" being a reference group.) Standard errors are clustered at the year of child birth level and appear in parentheses. $* \mathrm{p}<0.10, * * \mathrm{p}<0.05, * * *$ $\mathrm{p}<0.01$. 


\section{6. $\underline{\text { Conclusion }}$}

This paper considers the question of whether private property rights to land can improve child health and nutrition outcomes. We exploit a natural experiment in the Kyrgyz Republic following the collapse of socialism, whereby the government rapidly liquidated state and collective farms containing 75 percent of agricultural land and distributed it to individuals, providing 99-year transferrable use rights. We use household surveys collected before, during, and after the reform (repeated cross-sections) and spatial variation in the timing of privatization to identify its health and nutrition impacts. We find that young children aged 0-5 exposed to land privatization for longer periods of time accumulated significantly greater gains in height and weight, both critical measures of long-term health and nutrition. Health improvements appear to be driven by increases in consumption of home-produced food-suggesting that increased private control over personal production may translate into increased consumption and thus health dividends for the youngest and thus most vulnerable children.

While households in the Kyrgyz Republic accessed land prior to privatization, they did so predominately through small kitchen gardens and working on communal land which they neither owned nor managed. Our findings point to the important health value of actually having private control over a more sizeable amount of land (1.47 hectares on average during the 1996-1998 surveys, compared to 0.30 hectares on average during the 1993 survey). It is interesting that food purchases and non-food expenditures are not increasing with exposure to land privatization while food consumption is. It suggests either that households' food consumption was inframarginal prior to land privatization and/or that market frictions in the 1990s resulted in households predominately consuming rather than trading the increased home production that land privatization afforded them. Either way, this resulted in health benefits, in the form of higher HAZ and WAZ scores, that accrued mostly to both boys and girls aged 0-2.

Future research is needed to better understand the mechanisms delivering these results. For example, did productivity rise on the plots of land that were privatized, or is it simply the case that households (as opposed to the collective) were better able to retain and use what was produced? What did a switch from collective to private farming do to parental labor supply and time use, and how did this translate into changes in investments in children (e.g., more vs. less time spent with children, or monitoring and investing in their health)? Did access to a greater 
array of inputs, ability to decide what to plant or which livestock to rear, or freedom to market agricultural products as desired help in contributing to increased food consumption and child health gains? Interrogating these and other mechanisms will require more data on how individuals farmed in the Kyrgyz Republic before and after land privatizations.

More work is also needed to study whether these impacts hold up in modern-day contexts. Agricultural technology as well as information technology have changed drastically over the last two decades, changing rural service delivery and rural livelihoods (Kosec and Wantchekon 2020). Land markets and markets for goods and services have also changed. Understanding whether and how these changes magnify or blunt the effects of privately accessing land on child health is important for extrapolating from this work to made modern day policy recommendations. 


\section{References}

Alchian, A. A., \& Demsetz, H. (1973). “The property right paradigm.” Journal of Economic History, 33(1): 16-27.

Ali, D. A., Collin, M., Deininger, K., Dercon, S., Sandefur, J., \& Zeitlin, A. (2014). "The price of empowerment: Experimental evidence on land titling in Tanzania.” World Bank.

Allendorf, K. (2007). Do women's land rights promote empowerment and child health in Nepal?. World Development, 35(11), 1975-1988.

Alston, L. J., Libecap, G. D., \& Mueller, B. (1999). Titles, conflict, and land use: The development of property rights and land reform on the Brazilian Amazon frontier. University of Michigan Press.

Arimond, M., \& Ruel, M. T. (2004). Dietary diversity is associated with child nutritional status: evidence from 11 demographic and health surveys. Journal of Nutrition, 134(10), 25792585 .

Banerjee, A. V., Gertler, P. J., \& Ghatak, M. (2002). Empowerment and efficiency: tenancy reform in West Bengal. Journal of Political Economy, 110(2): 239-280.

Benjaminsen, T. A., \& Sjaastad, E. (2002). "Race for the prize: Land transactions and rent appropriation in the Malian cotton zone." European Journal of Development Research, 14(2): 129-152.

Besley, T. (1995). Property rights and investment incentives: Theory and evidence from Ghana. Journal of Political Economy, 103(5): 903-937.

Bloch, P. C. (2002). Agrarian reform in Uzbekistan and other Central Asian countries. Land Tenure Center Working Paper No. 49: University of Wisconsin-Madison.

Bloch, P.C. and K. Rasmussen. 1998. "Land Reform in Kyrgyzstan.” In Land Reform in the Former Soviet Union and Eastern Europe, edited by Stephen K. Wegren, pp. 111-135. London: Routledge.

Boyd, R., Richerson, P. J., Meinzen-Dick, R., De Moor, T., Jackson, M. O., Gjerde, K. M., ... \& McLean, A. R. (2018). Tragedy revisited. Science, 362(6420), 1236-1241.

Burgess, R. (2001). "Land and Welfare: Theory and Evidence from China." Unpublished manuscript. http://econ.lse.ac.uk/staff/rburgess/wp/land and welfare2.pdf (last accessed: December 13, 2018).

Burroway, R. (2015). Women's rights save lives: a cross-national analysis of infant and child mortality and Women's access to land, property, and loans in developing countries. Sociology of Development, 1(4), 418-441. 
Carter, M. R. (1987). "Risk sharing and incentives in the decollectivization of agriculture." Oxford Economic Papers, 39(3), 577-595.

Carter, M., and J. Maluccio (2003). "Social Capital and Coping with Economic Shocks: An Analysis of Stunting of South African Children." World Development, 31(7):1147-63.

Carter, M. R., \& Olinto, P. (2003). "Getting institutions 'right' for whom? Credit constraints and the impact of property rights on the quantity and composition of investment." American Journal of Agricultural Economics, 85(1): 173-186.

Deininger, K. (1995). "Collective agricultural production: A solution for transition economies?” World Development, 23(8): 1317-1334.

Deinlnger, K., \& Binswanger, H. (1999). "The evolution of the World Bank's land policy: principles, experience, and future challenges." The World Bank Research Observer, 14(2): 247-276.

Deininger, K., \& Feder, G. (2001). "Land institutions and land markets.” In Handbook of Agricultural Economics, 1: 287-331.

Deininger, K., \& Feder, G. (2009). "Land registration, governance, and development: Evidence and implications for policy." World Bank Research Observer, 24(2): 233-266.

Deininger, K., \& Ali, D. A. (2008). Do overlapping land rights reduce agricultural investment? Evidence from Uganda. American Journal of Agricultural Economics, 90(4): 869-882.

Deininger, K., Ali, D. A., \& Alemu, T. (2011). "Impacts of land certification on tenure security, investment, and land market participation: evidence from Ethiopia." Land Economics, 87(2): 312-334.

Delville, P. L. (2002). "When Farmers Use 'Pieces of Paper' to Record Their Land Transactions in Francophone Rural Africa: Insights into the Dynamics of Institutional Innovation." European Journal of Development Research, 14(2): 89-108.

De Meza, D., \& Gould, J. R. (1992). "The social efficiency of private decisions to enforce property rights." Journal of Political Economy, 100(3): 561-580.

Demsetz, H. (1967). "Toward a theory of property rights.” American Economic Review, 57(2): 347-59.

De Soto, H. (2000). The mystery of capital: Why capitalism triumphs in the West and fails everywhere else. Basic Civitas Books.

Dillon, A., McGee, K., \& Oseni, G. (2015). Agricultural production, dietary diversity and climate variability. Journal of Development Studies, 51(8): 976-995. 
Do, Q. T., \& Iyer, L. (2008). "Land titling and rural transition in Vietnam.” Economic Development and Cultural Change, 56(3): 531-579.

FAO (2015). "Food and Agriculture Organization of the United Nations Country Programming Framework in the Kyrgyz Republic, http://www.fao.org/3/a-au213e.pdf (last accessed September 2017).

Feder, G., Onchan, T., \& Chalamwong, Y. (1988). "Land policies and farm performance in Thailand's forest reserve areas." Economic Development and Cultural Change, 36(3): 483501.

Fenske, J. (2011). "Land tenure and investment incentives: Evidence from West Africa.” Journal of Development Economics, 95(2): 137-156.

Field, E. (2005). "Property rights and investment in urban slums." Journal of the European Economic Association, 3(2-3): 279-290.

Field, E. (2007). "Entitled to work: Urban property rights and labor supply in Peru." Quarterly Journal of Economics, 122(4): 1561-1602.

Galiani, S., \& Schargrodsky, E. (2004). "Effects of land titling on child health.” Economics and Human Biology, 2(3): 353-372.

Galiani, S., \& Schargrodsky, E. (2010). "Property rights for the poor: Effects of land titling." Journal of Public Economics, 94(9-10): 700-729.

Hidrobo, M. (2014). “The effect of Ecuador's 1999 economic crisis on early childhood development." Economic Development and Cultural Change, 62(4): 633-671.

Holden, S. T., Deininger, K., \& Ghebru, H. (2009). "Impacts of low-cost land certification on investment and productivity." American Journal of Agricultural Economics, 91(2): 359373.

Jansen, K., \& Roquas, E. (1998). "Modernizing insecurity: the land titling project in Honduras." Development and Change, 29(1): 81-106.

Jones, A. D., Shrinivas, A., \& Bezner-Kerr, R. (2014). "Farm production diversity is associated with greater household dietary diversity in Malawi: findings from nationally representative data." Food Policy, 46: 1-12.

Jones, K. D. (2004) "Land Privatization and Conflict in Central Asia: Is Kyrgyzstan a Model?", Chapter 12.

http://www.unece.org/fileadmin/DAM/hlm/prgm/cph/experts/kyrgyzstan/documents/Chap ter12.land.privatization.pdf 
Kosec, K., Ghebru, H., Holtemeyer, B., Mueller, V., \& Schmidt, E. (2018). "The Effect of Land Access on Youth Employment and Migration Decisions: Evidence from Rural Ethiopia." American Journal of Agricultural Economics, 100(3): 931-954.

Kosec, K., \& Wantchekon, L. (2020). Can information improve rural governance and service delivery? World Development, 125, 104376.

Kremer, M., Leino, J., Miguel, E., \& Zwane, A. P. (2011). "Spring cleaning: Rural water impacts, valuation, and property rights institutions." Quarterly Journal of Economics, 126(1): 145-205.

Lanjouw, J. O., \& Levy, P. I. (2002). Untitled: A study of formal and informal property rights in urban Ecuador. Economic Journal, 112(482): 986-1019.

Lawry, S., Samii, C., Hall, R., Leopold, A., Hornby, D., \& Mtero, F. (2017). “The impact of land property rights interventions on investment and agricultural productivity in developing countries: a systematic review." Journal of Development Effectiveness, 9(1): 61-81.

Leroy, J. (2011). "zscore06: Stata command for the calculation of anthropometric z-scores using the 2006 WHO child growth standards." http://www.ifpri.org/staffprofile/jef-leroy (last accessed September 2017).

Lipton, M. (2009). Land Reform in Developing Countries: Property Rights and Property Wrongs. London: Routledge.

Mathijs, E., \& Swinnen, J. F. (1998). "The economics of agricultural decollectivization in East Central Europe and the former Soviet Union." Economic Development and Cultural Change, 47(1): 1-26.

Meeks, R. (2018). Property rights and water access: Evidence from land titling in rural Peru. World Development, 102, 345-357.

Meinzen-Dick, R., \& Mwangi, E. (2009). "Cutting the web of interests: Pitfalls of formalizing property rights." Land Use Policy, 26(1): 36-43.

Menon, N., Van Der Meulen Rodgers, Y., \& Nguyen, H. (2014). Women's land rights and children's human capital in Vietnam. World Development, 54, 18-31.

Merten, S., \& Haller, T. (2008). Property rights, food security and child growth: Dynamics of insecurity in the Kafue Flats of Zambia. Food Policy, 33(5), 434-443.

Mogilevskii, R. (2016). Private interview by Olga Shemyakina: Bishkek, Kyrgyzstan.

Payne, G., Durand-Lasserve, A., \& Rakodi, C. (2009). "The limits of land titling and home ownership." Environment and Urbanization, 21(2): 443-462. 
Peters, P. E. (2004). "Inequality and social conflict over land in Africa." Journal of Agrarian Change, 4(3): 269-314.

Pryor, F. L. (2014). The red and the green: the rise and fall of collectivized agriculture in Marxist regimes. Princeton University Press.

Putterman, L. (1985). "Extrinsic versus intrinsic problems of agricultural cooperation: Antiincentivism in Tanzania and China." Journal of Development Studies, 21(2): 175-204.

Quisumbing, A. R., Brown, L. R., Feldstein, H. S., Haddad, L., \& Peña, C. (1996). Women: The key to food security. Food and Nutrition Bulletin, 17(1), 1-2.

Rozelle, S. (1996). Gradual reform and institutional development: The keys to success of China's agricultural reforms (pp. 197-220). The University of Michigan Press.

Shrimpton, R., C. Victora, M. de Onis, R. Lima, M. Blossner, and G. Clugston (2001). "Worldwide Timing of Growth Faltering: Implications for Nutritional Interventions." Pediatrics, 107(5): e75.

Sibhatu, K. T., Krishna, V. V., \& Qaim, M. (2015). "Production diversity and dietary diversity in smallholder farm households." Proceedings of the National Academy of Sciences, 112(34): 10657-10662.

Sitko, N. J., Chamberlin, J., \& Hichaambwa, M. (2014). "Does smallholder land titling facilitate agricultural growth?: An analysis of the determinants and effects of smallholder land titling in Zambia." World Development, 64: 791-802.

United Stated Agency for International Development (USAID) (2011) "Property Rights and Resource Governance: USAID Kyrgyzstan Country Profile," https://www.landlinks.org/country-profile/kyrgyzstan/ (last accessed: December 2019).

Vogl, T. S. (2007). "Urban land rights and child nutritional status in Peru, 2004." Economics and Human Biology, 5(2): 302-321.

World Bank. (1993). "Kyrgyzstan: The Transition to a Market Economy”. World Bank Country Study. Washington, D.C.

http://documents.worldbank.org/curated/en/586161468753276010/pdf/multi0page.pdf

World Bank. (1996). The 1993 Kyrgyzstan Multipurpose Poverty Survey: Documentation.

World Bank. (1998). Kyrgyz Republic - Agricultural policy review: strategy for rural growth and poverty alleviation (English). World Development Sources, WDS 1998-3. Washington, DC: World Bank. http://documents.worldbank.org/curated/en/887531468753343800/Kyrgyz-RepublicAgricultural-policy-review-strategy-for-rural-growth-and-poverty-alleviation 
World Bank. (2002). Kyrgyz Poverty Monitoring Surveys (KPMS): Fall 1996-Fall 1998. Basic Information Document.

World Bank (2017). "Databank." https://data.worldbank.org/topic/poverty?locations=KG (last accessed September 2017).

World Health Organization (WHO) (1997). "WHO Global Database on Child Growth and Malnutrition." World Health Organization: Geneva.

http://apps.who.int/iris/bitstream/10665/63750/1/WHO_NUT 97.4.pdf (last accessed September 2017).

Yaro, J. A. (2010). Customary tenure systems under siege: contemporary access to land in Northern Ghana. GeoJournal, 75(2), 199-214. 


\section{Appendix}

Figure A1: Exposure to land privatization by child age in years and oblast, over the four survey years
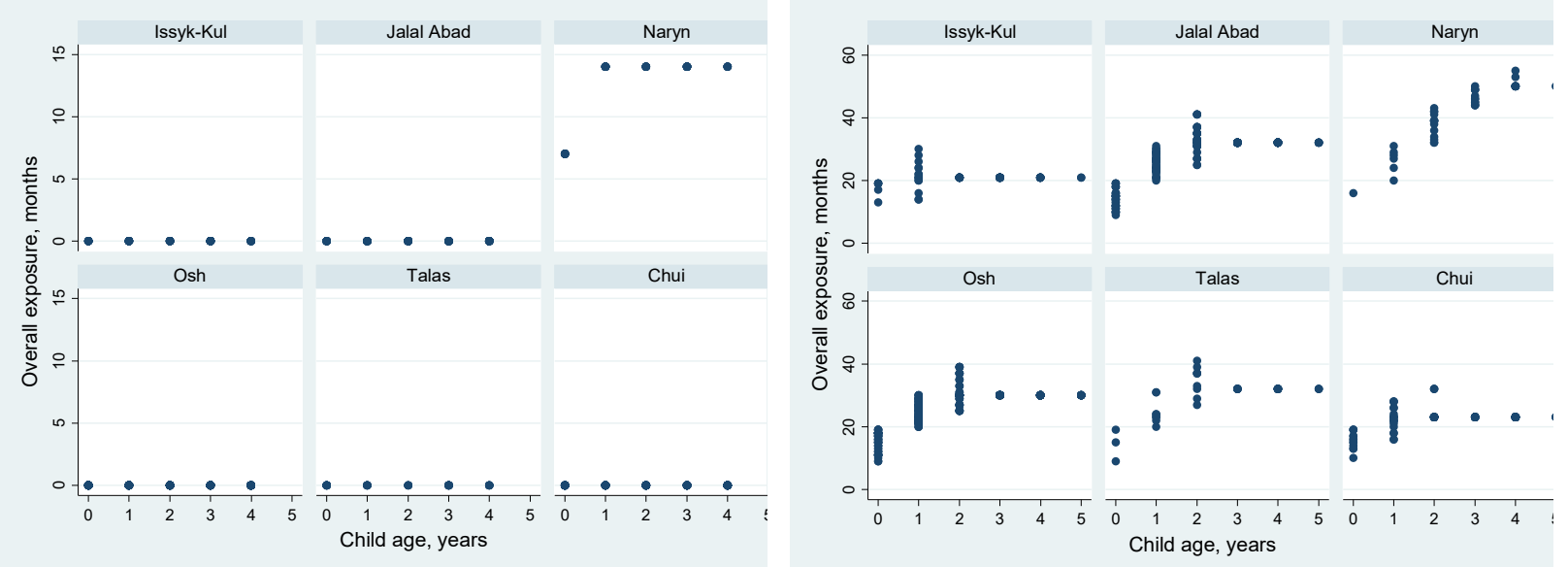

a) 1993

b) 1996
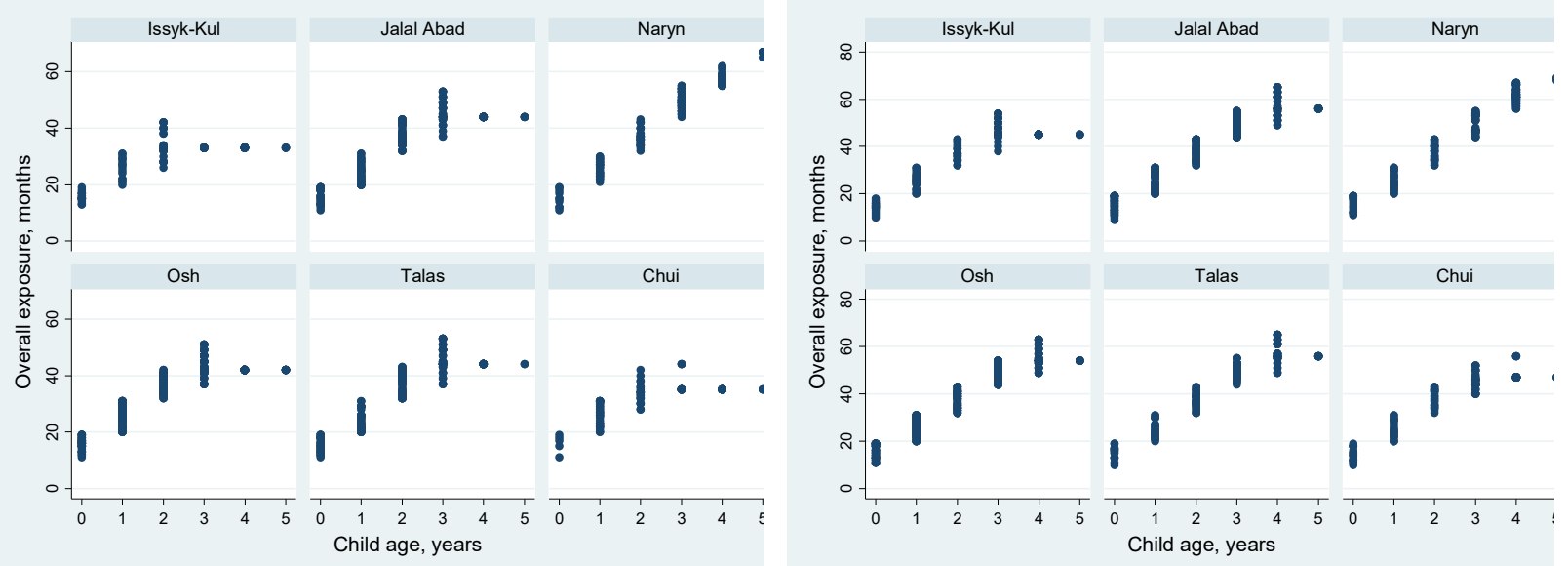

c) 1997

d) 1998

Source: World Bank LSMS (1993, 1996, 1997, and 1998).

Note: Overall exposure includes in utero period. 
Table A1: Calculation of child's age in months

\begin{tabular}{|c|c|c|c|c|c|c|c|}
\hline $\begin{array}{c}\text { Survey } \\
\text { year }\end{array}$ & $\begin{array}{l}\text { Month } \\
\text { survey } \\
\text { conducted }\end{array}$ & $\begin{array}{l}\text { Date of survey } \\
\text { administration } \\
\text { assumed for } \\
\text { child age } \\
\text { calculation }\end{array}$ & $\begin{array}{l}\text { Child age } \\
\text { in years } \\
\text { availability }\end{array}$ & $\begin{array}{c}\text { Year } \\
\text { of } \\
\text { birth } \\
\text { avail. }\end{array}$ & $\begin{array}{l}\text { Month } \\
\text { of } \\
\text { birth } \\
\text { avail. }\end{array}$ & $\begin{array}{c}\text { Day } \\
\text { of } \\
\text { birth } \\
\text { avail. }\end{array}$ & Age in months calculation \\
\hline$(1)$ & (2) & (3) & (4) & (5) & (6) & (7) & $(8)$ \\
\hline 1993 & Oct-Nov & 1-Nov-93 & YES & $\begin{array}{l}\text { based } \\
\text { on } \\
\text { age } \\
\text { in } \\
\text { years }\end{array}$ & $\mathrm{NO}$ & $\mathrm{NO}$ & $\begin{array}{l}\text { Assume that May (i.e., } 6 \\
\text { months before the survey date } \\
\text { of November) is the month of } \\
\text { birth for all children (given a } \\
\text { year) and calculate age in } \\
\text { months }\end{array}$ \\
\hline 1996 & Oct-Nov & 1-Nov-96 & YES & YES & YES & $\mathrm{NO}$ & survey date - birth date \\
\hline 1997 & Oct-Nov & 1-Nov-97 & YES & YES & YES & YES & survey date - birth date \\
\hline 1998 & Oct-Nov & 1-Nov-98 & YES & YES & YES & YES & survey date - birth date \\
\hline
\end{tabular}

Source: World Bank LSMS (1993, 1996, 1997, and 1998).

Table A2: Effect of exposure to land privatization on child anthropometrics, robustness to not including the 1993 data

\begin{tabular}{|c|c|c|c|c|c|c|c|c|c|}
\hline & \multicolumn{3}{|c|}{ Panel A: height for age z-scores } & \multicolumn{3}{|c|}{ Panel B: weight for age z-scores } & \multicolumn{3}{|c|}{ Panel C: weight for height z-scores } \\
\hline & All & $0-24 \mathrm{~m}$ & $25-60 \mathrm{~m}$ & All & $0-24 \mathrm{~m}$ & $25-60 \mathrm{~m}$ & All & $0-24 \mathrm{~m}$ & $25-60 \mathrm{~m}$ \\
\hline & (1) & $(2)$ & (3) & (4) & $(5)$ & (6) & (7) & $(8)$ & (9) \\
\hline Months exposed overall & 0.016 & -0.043 & 0.000 & $0.014^{*}$ & $-0.027 * *$ & -0.003 & 0.010 & 0.018 & 0.022 \\
\hline (including in utero period) & $(0.009)$ & $(0.031)$ & $(0.012)$ & $(0.007)$ & $(0.008)$ & $(0.008)$ & $(0.007)$ & $(0.022)$ & $(0.013)$ \\
\hline \multirow[t]{2}{*}{ Child is female } & $0.241 *$ & 0.547 & 0.116 & 0.073 & $0.226^{* *}$ & 0.044 & -0.078 & -0.036 & -0.091 \\
\hline & $(0.118)$ & $(0.265)$ & $(0.058)$ & $(0.081)$ & $(0.061)$ & $(0.092)$ & $(0.069)$ & $(0.178)$ & $(0.056)$ \\
\hline \multirow[t]{2}{*}{ Survey 1997} & $-0.409 * *$ & $-0.463 * *$ & -0.106 & $-0.369 * * *$ & $-0.537 * * *$ & -0.061 & $-0.512 * * *$ & $-0.294^{*}$ & $-0.784 * *$ \\
\hline & $(0.121)$ & $(0.120)$ & $(0.152)$ & $(0.091)$ & $(0.110)$ & $(0.105)$ & $(0.121)$ & $(0.128)$ & $(0.195)$ \\
\hline \multirow[t]{2}{*}{ Survey 1998} & -0.269 & $-0.467 *$ & 0.189 & $-0.251^{* *}$ & $-0.465 * * *$ & 0.168 & $-0.497 * * *$ & $-0.278^{*}$ & $-0.837 * *$ \\
\hline & $(0.165)$ & $(0.187)$ & $(0.218)$ & $(0.106)$ & $(0.077)$ & $(0.133)$ & $(0.109)$ & $(0.112)$ & $(0.273)$ \\
\hline Age in months FE & Yes & Yes & Yes & Yes & Yes & Yes & Yes & Yes & Yes \\
\hline Oblast FE & Yes & Yes & Yes & Yes & Yes & Yes & Yes & Yes & Yes \\
\hline HH Head controls & Yes & Yes & Yes & Yes & Yes & Yes & Yes & Yes & Yes \\
\hline $\mathrm{N}$ & 2663 & 825 & 1782 & 3087 & 984 & 2038 & 2387 & 750 & 1584 \\
\hline $\mathrm{R}$ squared & 0.06 & 0.10 & 0.06 & 0.05 & 0.06 & 0.06 & 0.05 & 0.05 & 0.06 \\
\hline
\end{tabular}

Notes: These are OLS regressions using the sample of children aged 0-60 months old at the time of the survey.

"All", "0-24m" and "25-60m" refer to children aged 0-60, 0-24, and 25-60 months old, respectively, at the time of the survey. The regressions are estimated for the sub-sample of children living in rural areas. "Months exposed overall (including in utero period)" is the number of months a child was alive while land privatization was in place. The date of land reform (to calculate months of exposure) is based on the 2016 Life in Kyrgyzstan Study (which provided the month and year). Standard errors are clustered at the year of child birth level and appear in parentheses. $* \mathrm{p}<0.10, * * \mathrm{p}<0.05, * * * \mathrm{p}<0.01$.

Source: World Bank LSMS (1996, 1997 and 1998) and Life In Kyrgyzstan Study (2016). 
Table A3: Effect of exposure to land privatization on child anthropometrics, robustness to omitting household head controls

\begin{tabular}{|c|c|c|c|c|c|c|c|c|c|}
\hline & \multicolumn{3}{|c|}{ Panel A: height for age z-scores } & \multicolumn{3}{|c|}{ Panel B: weight for age z-scores } & \multicolumn{3}{|c|}{ Panel C: weight for height $\mathrm{z}$-scores } \\
\hline & All & $0-24 \mathrm{~m}$ & $25-60 \mathrm{~m}$ & All & $0-24 \mathrm{~m}$ & $25-60 \mathrm{~m}$ & All & $0-24 \mathrm{~m}$ & $25-60 \mathrm{~m}$ \\
\hline \multirow{3}{*}{$\begin{array}{l}\text { Months exposed overall } \\
\text { (including in utero period) }\end{array}$} & (1) & (2) & (3) & (4) & (5) & (6) & $(7)$ & (8) & (9) \\
\hline & $0.029 * * *$ & $0.115^{*}$ & 0.008 & $0.026^{* * *}$ & $0.068 * *$ & 0.002 & 0.01 & -0.014 & $0.017^{*}$ \\
\hline & $(0.006)$ & $(0.049)$ & $(0.011)$ & $(0.007)$ & $(0.025)$ & $(0.007)$ & $(0.008)$ & $(0.030)$ & $(0.009)$ \\
\hline \multirow[t]{2}{*}{ Child is female } & $0.188^{*}$ & $0.488^{*}$ & 0.061 & 0.04 & $0.181 *$ & 0.001 & -0.069 & -0.017 & -0.074 \\
\hline & $(0.096)$ & $(0.225)$ & $(0.049)$ & $(0.077)$ & $(0.081)$ & $(0.086)$ & $(0.058)$ & $(0.126)$ & $(0.064)$ \\
\hline Survey 1993 & ref. & ref. & ref. & ref. & ref. & ref. & ref. & ref. & ref. \\
\hline \multirow[t]{2}{*}{ Survey 1996} & $-1.778 * * *$ & $-3.870 * * *$ & $-1.015^{* *}$ & $-1.317 * * *$ & $-2.453 * * *$ & $-0.478^{*}$ & -0.022 & 0.277 & -0.161 \\
\hline & $(0.138)$ & $(0.878)$ & $(0.412)$ & $(0.226)$ & $(0.628)$ & $(0.217)$ & $(0.263)$ & $(0.908)$ & $(0.296)$ \\
\hline \multirow[t]{2}{*}{ Survey 1997} & $-2.286^{* * *}$ & $-4.510 * * *$ & $-1.213^{* *}$ & $-1.741 * * *$ & $-3.100 * * *$ & $-0.549 *$ & -0.496 & 0.034 & $-0.822 *$ \\
\hline & $(0.187)$ & $(0.933)$ & $(0.482)$ & $(0.276)$ & $(0.637)$ & $(0.265)$ & $(0.333)$ & $(0.912)$ & $(0.371)$ \\
\hline \multirow[t]{2}{*}{ Survey 1998} & $-2.228 * * *$ & $-4.517 * * *$ & -1.013 & $-1.700 * * *$ & $-3.016^{* * *}$ & -0.363 & -0.465 & 0.121 & $-0.857^{*}$ \\
\hline & $(0.223)$ & $(0.935)$ & $(0.550)$ & $(0.334)$ & $(0.674)$ & $(0.298)$ & $(0.344)$ & $(0.922)$ & $(0.424)$ \\
\hline Age in months FE & Yes & Yes & Yes & Yes & Yes & Yes & Yes & Yes & Yes \\
\hline Oblast FE & Yes & Yes & Yes & Yes & Yes & Yes & Yes & Yes & Yes \\
\hline $\mathrm{N}$ & 3335 & 1031 & 2304 & 3823 & 1208 & 2615 & 3072 & 1001 & 2071 \\
\hline $\mathrm{R}$ squared & 0.12 & 0.21 & 0.07 & 0.06 & 0.11 & 0.05 & 0.04 & 0.04 & 0.04 \\
\hline
\end{tabular}

Notes: These are OLS regressions using the sample of children aged 0-60 months old at the time of the survey. "All", " $0-24 \mathrm{~m} "$ and " $25-60 \mathrm{~m} "$ refer to children aged 0-60, 0-24, and 25-60 months old, respectively, at the time of the survey. The regressions are estimated for the sub-sample of children living in rural areas. "Months exposed overall (including in utero period)" is the number of months a child was alive while land privatization was in place. The date of land reform (to calculate months of exposure) is based on the 2016 Life in Kyrgyzstan Study (which provided the month and year). Standard errors are clustered at the year of child birth level and appear in parentheses. $* \mathrm{p}<0.10, * * \mathrm{p}<0.05, * * * \mathrm{p}<0.01$.

Source: World Bank LSMS (1993, 1996, 1997 and 1998) and Life In Kyrgyzstan Study (2016). 
Table A4: Effect of exposure to land privatization on child anthropometrics, controlling for the availability of land

\begin{tabular}{lcccccc}
\hline & \multicolumn{2}{c}{ Panel A: height for age z-scores } & \multicolumn{3}{c}{ Panel B: weight for age z-scores } \\
\cline { 2 - 7 } & All & $0-24 \mathrm{~m}$ & $25-60 \mathrm{~m}$ & All & $0-24 \mathrm{~m}$ & $25-60 \mathrm{~m}$ \\
\hline \multirow{3}{*}{ Months exposed overall (including } & $(1)$ & $(2)$ & $(3)$ & $(4)$ & $(5)$ & $(6)$ \\
in utero period) & $0.030^{* * *}$ & $0.114^{*}$ & 0.006 & $0.026^{* * *}$ & $0.072^{* *}$ & 0.002 \\
Child is female & $(0.007)$ & $(0.050)$ & $(0.011)$ & $(0.008)$ & $(0.025)$ & $(0.008)$ \\
& $0.179^{*}$ & $0.461^{*}$ & 0.058 & 0.042 & $0.195^{*}$ & 0.008 \\
Survey 1993 & $(0.095)$ & $(0.202)$ & $(0.062)$ & $(0.069)$ & $(0.085)$ & $(0.081)$ \\
Survey 1996 & ref. & ref. & ref. & ref. & ref. & ref. \\
& $-1.757^{* * *}$ & $-3.856^{* * *}$ & $-0.916^{* *}$ & $-1.319^{* * *}$ & $-2.637^{* * *}$ & -0.432 \\
Survey 1997 & $(0.180)$ & $(0.853)$ & $(0.385)$ & $(0.231)$ & $(0.584)$ & $(0.231)$ \\
& $-2.184^{* * *}$ & $-4.354^{* * *}$ & $-1.014^{*}$ & $-1.707^{* * *}$ & $-3.241^{* * *}$ & -0.466 \\
Survey 1998 & $(0.240)$ & $(0.909)$ & $(0.440)$ & $(0.279)$ & $(0.618)$ & $(0.277)$ \\
& $-2.158^{* * *}$ & $-4.428^{* * *}$ & -0.817 & $-1.678^{* * *}$ & $-3.157^{* * *}$ & -0.294 \\
HH has land & $(0.282)$ & $(0.936)$ & $(0.533)$ & $(0.338)$ & $(0.616)$ & $(0.329)$ \\
& $-0.487 * * *$ & $-0.712^{* * *}$ & $-0.394^{* *}$ & $-0.313^{* *}$ & -0.213 & $-0.359^{* *}$ \\
Hectares of land in HH posession & $(0.112)$ & $(0.158)$ & $(0.153)$ & $(0.110)$ & $(0.210)$ & $(0.125)$ \\
& $0.013^{* * *}$ & 0.008 & $0.016^{* * *}$ & $0.012^{* * *}$ & 0.007 & $0.016^{* * *}$ \\
Age in months FE & $(0.002)$ & $(0.006)$ & $(0.002)$ & $(0.003)$ & $(0.006)$ & $(0.002)$ \\
Oblast FE & Yes & Yes & Yes & Yes & Yes & Yes \\
HH Head controls & Yes & Yes & Yes & Yes & Yes & Yes \\
\hline $\mathrm{N}$ & Yes & Yes & Yes & Yes & Yes & Yes \\
R squared & 3295 & 1019 & 2276 & 3774 & 1194 & 2580 \\
\hline
\end{tabular}

Notes: These are OLS regressions using the sample of children aged 0-60 months old at the time of the survey. "All", "0-24m" and "25-60m" refer to children aged 0-60, 0-24, and 25-60 months old, respectively, at the time of the survey. The regressions are estimated for the sub-sample of children living in rural areas. "Months exposed overall (including in utero period)" is the number of months a child was alive while land privatization was in place. The date of land reform (to calculate months of exposure) is based on the 2016 Life in Kyrgyzstan Study (which provided the month and year). "Hectares of land in HH possession" is the amount of land that the respondent indicates that the household can access. Households with "zero" amount of land reported are included in the analysis. Standard errors are clustered at the year of child birth level and appear in parentheses. ${ }^{*} \mathrm{p}<0.10,{ }^{* *} \mathrm{p}<0.05$, $* * * \mathrm{p}<0.01$.

Source: World Bank LSMS (1993, 1996, 1997 and 1998) and Life In Kyrgyzstan Study (2016). 
Table A5: Effect of exposure to land privatization on child anthropometrics, using logged value of exposure to reform

\begin{tabular}{lcccccc}
\hline & \multicolumn{3}{c}{ Panel A: height for age z-scores } & \multicolumn{3}{c}{ Panel B: weight for age z-scores } \\
& All & $0-24 \mathrm{~m}$ & $25-60 \mathrm{~m}$ & All & $0-24 \mathrm{~m}$ & $25-60 \mathrm{~m}$ \\
\hline & $(1)$ & $(2)$ & $(3)$ & $(4)$ & $(5)$ & $(6)$ \\
Log [months exposed overall & $0.135^{* *}$ & 0.172 & $0.071^{* *}$ & $0.075^{* *}$ & 0.053 & 0.052 \\
(including in utero period)] (replace & & & & & & \\
0 values with 0.001) & $(0.058)$ & $(0.126)$ & $(0.025)$ & $(0.025)$ & $(0.047)$ & $(0.032)$ \\
Child is female & $0.196^{*}$ & $0.491^{*}$ & 0.063 & 0.044 & $0.197^{*}$ & 0.003 \\
& $(0.094)$ & $(0.207)$ & $(0.058)$ & $(0.074)$ & $(0.086)$ & $(0.084)$ \\
Survey 1993 & ref. & ref. & ref. & ref. & ref. & ref. \\
Survey 1996 & $-2.273^{* * *}$ & $-3.122^{* *}$ & $-1.477^{* * *}$ & $-1.357^{* * *}$ & $-1.604^{* * *}$ & $-0.962^{* *}$ \\
& $(0.602)$ & $(0.886)$ & $(0.301)$ & $(0.259)$ & $(0.201)$ & $(0.328)$ \\
Survey 1997 & $-2.570^{* * *}$ & $-3.587^{* * *}$ & $-1.607^{* * *}$ & $-1.624^{* * *}$ & $-2.178^{* * *}$ & $-1.058^{* *}$ \\
& $(0.563)$ & $(0.898)$ & $(0.253)$ & $(0.290)$ & $(0.243)$ & $(0.331)$ \\
Survey 1998 & $-2.378^{* * *}$ & $-3.601 * * *$ & $-1.361^{* * *}$ & $-1.450^{* * *}$ & $-2.101^{* * *}$ & $-0.850^{* *}$ \\
& $(0.579)$ & $(0.899)$ & $(0.269)$ & $(0.292)$ & $(0.200)$ & $(0.318)$ \\
\hline N & 3315 & 1025 & 2290 & 3799 & 1200 & 2599 \\
R squared & 0.12 & 0.21 & 0.08 & 0.06 & 0.11 & 0.05 \\
\hline
\end{tabular}

Notes: These are OLS regressions using the sample of children aged 0-60 months old at the time of the survey.

"All", "0-24m" and " $25-60 \mathrm{~m}$ " refer to children aged 0-60, 0-24, and 25-60 months old, respectively, at the time of the survey. The regressions are estimated for the sub-sample of children living in rural areas. "Months exposed overall (including in utero period)" is the number of months a child was alive while land privatization was in place. The date of land reform (to calculate months of exposure) is based on the 2016 Life in Kyrgyzstan Study (which provided the month and year). Standard errors are clustered at the year of child birth level and appear in parentheses. $* \mathrm{p}<0.10,{ }^{* *} \mathrm{p}<0.05, * * * \mathrm{p}<0.01$.

Source: World Bank LSMS (1993, 1996, 1997, and 1998) and Life In Kyrgyzstan Study (2016). 
Table A6: Effect of exposure to land privatization on child anthropometrics, with modifications to reform date $(+/-$ one year)

\begin{tabular}{|c|c|c|c|c|c|c|c|c|c|}
\hline & \multicolumn{9}{|c|}{ Panel A: One year forward (move effect of reform by one year later or a delayed response) } \\
\hline & \multicolumn{3}{|c|}{ Height for age z-scores } & \multicolumn{3}{|c|}{ Weight for age z-scores } & \multicolumn{3}{|c|}{ Weight for height $\mathrm{z}$-scores } \\
\hline & All & $0-24 \mathrm{~m}$ & $25-60 \mathrm{~m}$ & All & $0-24 \mathrm{~m}$ & $25-60 \mathrm{~m}$ & All & $0-24 \mathrm{~m}$ & $25-60 \mathrm{~m}$ \\
\hline & (1) & (2) & (3) & (4) & (5) & (6) & $(7)$ & $(8)$ & (9) \\
\hline $\begin{array}{l}\text { Months exposed overall } \\
\text { (including in utero period) }\end{array}$ & $\begin{array}{l}0.018^{*} \\
(0.009)\end{array}$ & $\begin{array}{c}0.032 \\
(0.043)\end{array}$ & $\begin{array}{l}-0.006 \\
(0.017)\end{array}$ & $\begin{array}{l}0.022 * * * \\
(0.006)\end{array}$ & $\begin{array}{l}0.060^{* * *} \\
(0.015)\end{array}$ & $\begin{array}{l}-0.011 \\
(0.009)\end{array}$ & $\begin{array}{c}0.009 \\
(0.009)\end{array}$ & $\begin{array}{c}0.034 \\
(0.025)\end{array}$ & $\begin{array}{l}0.006 \\
(0.013)\end{array}$ \\
\hline Child is female & $\begin{array}{l}0.194^{*} \\
(0.094)\end{array}$ & $\begin{array}{l}0.467^{*} \\
(0.219)\end{array}$ & $\begin{array}{c}0.066 \\
(0.063)\end{array}$ & $\begin{array}{c}0.046 \\
(0.075)\end{array}$ & $\begin{array}{l}0.195^{*} \\
(0.082)\end{array}$ & $\begin{array}{c}0.012 \\
(0.087)\end{array}$ & $\begin{array}{l}-0.071 \\
(0.060)\end{array}$ & $\begin{array}{l}-0.008 \\
(0.128)\end{array}$ & $\begin{array}{l}-0.067 \\
(0.064)\end{array}$ \\
\hline Survey 1993 & ref. & ref. & ref. & ref. & ref. & ref. & ref. & ref. & ref. \\
\hline Survey 1996 & $\begin{array}{c}-1.289^{* * *} \\
(0.142)\end{array}$ & $\begin{array}{l}-2.078^{* *} \\
(0.662)\end{array}$ & $\begin{array}{l}-0.696^{*} \\
(0.303)\end{array}$ & $\begin{array}{c}-1.033^{* * *} \\
(0.177)\end{array}$ & $\begin{array}{c}-2.165^{* * *} \\
(0.515)\end{array}$ & $\begin{array}{c}-0.251 \\
(0.148)\end{array}$ & $\begin{array}{c}0.013 \\
(0.188)\end{array}$ & $\begin{array}{l}-0.622 \\
(0.683)\end{array}$ & $\begin{array}{c}0.195 \\
(0.291)\end{array}$ \\
\hline Survey 1997 & $\begin{array}{c}-1.749 * * * \\
(0.249)\end{array}$ & $\begin{array}{l}-2.705^{* *} \\
(0.874)\end{array}$ & $\begin{array}{l}-0.725 \\
(0.474)\end{array}$ & $\begin{array}{l}-1.500^{* * *} \\
(0.224)\end{array}$ & $\begin{array}{c}-3.029 * * * \\
(0.598)\end{array}$ & $\begin{array}{l}-0.183 \\
(0.241)\end{array}$ & $\begin{array}{l}-0.498 \\
(0.299)\end{array}$ & $\begin{array}{l}-1.056 \\
(0.752)\end{array}$ & $\begin{array}{l}-0.409 \\
(0.446)\end{array}$ \\
\hline Survey 1998 & $\begin{array}{c}-1.673^{* * *} \\
(0.302) \\
\end{array}$ & $\begin{array}{l}-2.767^{* *} \\
(0.897) \\
\end{array}$ & $\begin{array}{l}-0.391 \\
(0.607) \\
\end{array}$ & $\begin{array}{c}-1.478^{* * *} \\
(0.284) \\
\end{array}$ & $\begin{array}{c}-3.005^{* * *} \\
(0.621) \\
\end{array}$ & $\begin{array}{c}0.131 \\
(0.336)\end{array}$ & $\begin{array}{l}-0.494 \\
(0.324)\end{array}$ & $\begin{array}{c}-1.04 \\
(0.785)\end{array}$ & $\begin{array}{c}-0.362 \\
(0.569)\end{array}$ \\
\hline $\mathrm{N}$ & 3315 & 1025 & 2234 & 3799 & 1200 & 2534 & 3050 & 994 & 2003 \\
\hline \multirow[t]{4}{*}{ R squared } & 0.12 & 0.20 & 0.08 & 0.06 & 0.11 & 0.05 & 0.04 & 0.04 & 0.04 \\
\hline & \multicolumn{9}{|c|}{ Panel B: One year backwards (move effect of reform by one year earlier or an anticipatory effect) } \\
\hline & All & $0-24 \mathrm{~m}$ & $25-60 \mathrm{~m}$ & All & $0-24 \mathrm{~m}$ & $25-60 \mathrm{~m}$ & All & $0-24 \mathrm{~m}$ & $25-60 \mathrm{~m}$ \\
\hline & (1) & $(2)$ & (3) & (4) & $(5)$ & $(6)$ & $(7)$ & $(8)$ & (9) \\
\hline $\begin{array}{l}\text { Months exposed overall } \\
\text { (including in utero period) }\end{array}$ & $\begin{array}{c}0.045^{* * *} \\
(0.006)\end{array}$ & $\begin{array}{l}0.087^{* * *} \\
(0.017)\end{array}$ & $\begin{array}{l}0.033^{* * *} \\
(0.008)\end{array}$ & $\begin{array}{c}0.038^{* * *} \\
(0.005)\end{array}$ & $\begin{array}{l}0.083 * * * \\
(0.020)\end{array}$ & $\begin{array}{l}0.025^{* * *} \\
(0.005)\end{array}$ & $\begin{array}{l}0.012 * \\
(0.006)\end{array}$ & $\begin{array}{c}0.025 \\
(0.019)\end{array}$ & $\begin{array}{l}0.020^{* *} \\
(0.006)\end{array}$ \\
\hline Child is female & $\begin{array}{l}0.189^{*} \\
(0.095)\end{array}$ & $\begin{array}{l}0.475^{*} \\
(0.210)\end{array}$ & $\begin{array}{c}0.059 \\
(0.064)\end{array}$ & $\begin{array}{c}0.045 \\
(0.072)\end{array}$ & $\begin{array}{l}0.194^{*} \\
(0.083)\end{array}$ & $\begin{array}{c}0.007 \\
(0.085)\end{array}$ & $\begin{array}{l}-0.073 \\
(0.059)\end{array}$ & $\begin{array}{l}-0.011 \\
(0.130)\end{array}$ & $\begin{array}{l}-0.072 \\
(0.062)\end{array}$ \\
\hline Survey 1993 & ref. & ref. & ref. & ref. & ref. & ref. & ref. & ref. & ref. \\
\hline Survey 1996 & $\begin{array}{c}-2.226^{* * *} \\
(0.197)\end{array}$ & $\begin{array}{c}-2.610^{* * *} \\
(0.234)\end{array}$ & $\begin{array}{c}-1.926^{* * *} \\
(0.190)\end{array}$ & $\begin{array}{c}-1.720 * * * \\
(0.204)\end{array}$ & $\begin{array}{c}-2.218^{* * *} \\
(0.322)\end{array}$ & $\begin{array}{c}-1.329 * * * \\
(0.204)\end{array}$ & $\begin{array}{l}-0.142 \\
(0.266)\end{array}$ & $\begin{array}{l}-0.376 \\
(0.540)\end{array}$ & $\begin{array}{c}-0.399 \\
(0.337)\end{array}$ \\
\hline Survey 1997 & $\begin{array}{c}-2.707^{* * *} \\
(0.219)\end{array}$ & $\begin{array}{c}-3.073 * * * \\
(0.223)\end{array}$ & $\begin{array}{c}-2.259^{* * *} \\
(0.233)\end{array}$ & $\begin{array}{c}-2.142^{* * * *} \\
(0.201)\end{array}$ & $\begin{array}{c}-2.779 * * * \\
(0.305)\end{array}$ & $\begin{array}{c}-1.577 * * * \\
(0.218)\end{array}$ & $\begin{array}{l}-0.608^{*} \\
(0.274)\end{array}$ & $\begin{array}{l}-0.629 \\
(0.500)\end{array}$ & $\begin{array}{c}-1.070 * * * \\
(0.268)\end{array}$ \\
\hline Survey 1998 & $\begin{array}{c}-2.592^{* * *} \\
(0.247) \\
\end{array}$ & $\begin{array}{c}-3.108^{* * *} \\
(0.290) \\
\end{array}$ & $\begin{array}{c}-2.074 * * * \\
(0.269) \\
\end{array}$ & $\begin{array}{c}-2.033^{* * *} \\
(0.239) \\
\end{array}$ & $\begin{array}{c}-2.710^{* * *} \\
(0.360) \\
\end{array}$ & $\begin{array}{c}-1.442 * * * \\
(0.233) \\
\end{array}$ & $\begin{array}{l}-0.557^{*} \\
(0.265)\end{array}$ & $\begin{array}{r}-0.585 \\
(0.489) \\
\end{array}$ & $\begin{array}{c}-1.011^{* *} \\
(0.316) \\
\end{array}$ \\
\hline $\mathrm{N}$ & 3315 & 1025 & 2234 & 3799 & 1200 & 2534 & 3050 & 994 & 2003 \\
\hline R squared & 0.13 & 0.21 & 0.08 & 0.07 & 0.12 & 0.05 & 0.04 & 0.04 & 0.05 \\
\hline
\end{tabular}

Notes: These are OLS regressions using the sample of children aged 0-60 months old at the time of the survey. "All", "0-24m" and "25-60m" refer to children aged 0-60, 0-24, and 25-60 months old, respectively, at the time of the survey. The regressions are estimated for the sub-sample of children living in rural areas. "Months exposed overall (including in utero period)" is the number of months a child was alive while land privatization was in place. The date of land reform (to calculate months of exposure) is based on the 2016 Life in Kyrgyzstan Study (which provided the month and year). In Panel A the assumed date of exposure is moved one year forward to allow for lagged response. In Panel B, the assumed date of reform is moved one year earlier to allow for anticipatory effects. All regressions include controls for household head age, gender, marital status, and ethnicity (Russian, Kyrgyz, Uzbek, with "other" being a reference group), child age in months fixed effects and oblast of residence fixed effects. Standard errors are clustered at the year of child birth level and appear in parentheses. $* \mathrm{p}<0.10, * * \mathrm{p}<0.05, * * * \mathrm{p}<0.01$.

Source: World Bank LSMS (1993, 1996, 1997 and 1998) and Life In Kyrgyzstan Study (2016). 
Table A7: Effect of exposure to land privatization on child health, by urban residence status

\begin{tabular}{|c|c|c|c|c|c|c|c|c|c|}
\hline & \multicolumn{3}{|c|}{ Panel A: height for age z-scores } & \multicolumn{3}{|c|}{ Panel B: weight for age z-scores } & \multicolumn{3}{|c|}{ Panel C: weight for height z-scores } \\
\hline & All & $0-24 \mathrm{~m}$ & $25-60 \mathrm{~m}$ & All & $0-24 \mathrm{~m}$ & $25-60 \mathrm{~m}$ & All & $0-24 m$ & $25-60 \mathrm{~m}$ \\
\hline & (1) & $(2)$ & (3) & (4) & $(5)$ & (6) & (7) & $(8)$ & (9) \\
\hline Months exposed overall & $0.029 * * *$ & $0.111^{*}$ & 0.006 & $0.026^{* * *}$ & $0.070^{* *}$ & 0.002 & 0.011 & -0.01 & $0.019^{*}$ \\
\hline (including in utero period) & $(0.007)$ & $(0.047)$ & $(0.011)$ & $(0.008)$ & $(0.024)$ & $(0.008)$ & $(0.008)$ & $(0.029)$ & $(0.010)$ \\
\hline Overall exposed*Urban & $\begin{array}{c}-0.031 \text { *** } \\
(0.007)\end{array}$ & $\begin{array}{l}-0.117 \\
(0.061)\end{array}$ & $\begin{array}{l}-0.014 \\
(0.013)\end{array}$ & $\begin{array}{l}-0.016^{*} \\
(0.008)\end{array}$ & $\begin{array}{c}-0.096^{* *} \\
(0.030)\end{array}$ & $\begin{array}{c}0.004 \\
(0.006)\end{array}$ & $\begin{array}{c}0.01 \\
(0.009)\end{array}$ & $\begin{array}{l}-0.005 \\
(0.030)\end{array}$ & $\begin{array}{c}0.001 \\
(0.013)\end{array}$ \\
\hline Survey 1993 & ref. & ref. & ref. & ref. & ref. & ref. & ref. & ref. & ref. \\
\hline Survey 1996 & $\begin{array}{c}-1.766^{* * *} \\
(0.167)\end{array}$ & $\begin{array}{c}-3.801 * * * \\
(0.798)\end{array}$ & $\begin{array}{c}-0.965^{* *} \\
(0.400)\end{array}$ & $\begin{array}{c}-1.351^{* * *} \\
(0.229)\end{array}$ & $\begin{array}{c}-2.575^{* * *} \\
(0.588)\end{array}$ & $\begin{array}{l}-0.501 * \\
(0.233)\end{array}$ & $\begin{array}{l}-0.125 \\
(0.279)\end{array}$ & $\begin{array}{c}0.148 \\
(0.886)\end{array}$ & $\begin{array}{l}-0.284 \\
(0.318)\end{array}$ \\
\hline Survey 1997 & $\begin{array}{c}-2.263 * * * \\
(0.224)\end{array}$ & $\begin{array}{c}-4.374 * * * \\
(0.845)\end{array}$ & $\begin{array}{c}-1.148^{* *} \\
(0.467)\end{array}$ & $\begin{array}{c}-1.794 * * * \\
(0.275)\end{array}$ & $\begin{array}{c}-3.215^{* * *} \\
(0.605)\end{array}$ & $\begin{array}{l}-0.602 * \\
(0.278)\end{array}$ & $\begin{array}{l}-0.626 \\
(0.352)\end{array}$ & $\begin{array}{l}-0.095 \\
(0.880)\end{array}$ & $\begin{array}{c}-0.989^{* *} \\
(0.380)\end{array}$ \\
\hline Survey 1998 & $\begin{array}{c}-2.206^{* * *} \\
(0.263)\end{array}$ & $\begin{array}{c}-4.399 * * * \\
(0.874)\end{array}$ & $\begin{array}{l}-0.936 \\
(0.549)\end{array}$ & $\begin{array}{c}-1.741 * * * \\
(0.333)\end{array}$ & $\begin{array}{c}-3.138^{* * *} \\
(0.609)\end{array}$ & $\begin{array}{l}-0.397 \\
(0.321)\end{array}$ & $\begin{array}{l}-0.608 \\
(0.357)\end{array}$ & $\begin{array}{l}-0.053 \\
(0.889)\end{array}$ & $\begin{array}{l}-1.028^{*} \\
(0.447)\end{array}$ \\
\hline Survey $1996^{*}$ Urban & $\begin{array}{l}1.003 * \\
(0.543)\end{array}$ & $\begin{array}{c}0.46 \\
(1.149)\end{array}$ & $\begin{array}{c}0.914 \\
(0.665)\end{array}$ & $\begin{array}{l}0.587^{* *} \\
(0.230)\end{array}$ & $\begin{array}{c}2.313^{* *} \\
(0.862)\end{array}$ & $\begin{array}{l}-0.218 \\
(0.345)\end{array}$ & $\begin{array}{c}0.01 \\
(0.306)\end{array}$ & $\begin{array}{c}1.417 \\
(0.806)\end{array}$ & $\begin{array}{l}-0.198 \\
(0.466)\end{array}$ \\
\hline Survey 1997*Urban & $\begin{array}{l}1.239^{* *} \\
(0.458)\end{array}$ & $\begin{array}{c}0.773 \\
(1.135)\end{array}$ & $\begin{array}{c}0.882 \\
(0.604)\end{array}$ & $\begin{array}{c}0.838^{* * *} \\
(0.229)\end{array}$ & $\begin{array}{c}2.418^{* * *} \\
(0.608)\end{array}$ & $\begin{array}{l}-0.138 \\
(0.361)\end{array}$ & $\begin{array}{c}0.494 \\
(0.366)\end{array}$ & $\begin{array}{c}1.172 \\
(0.844)\end{array}$ & $\begin{array}{c}0.67 \\
(0.513)\end{array}$ \\
\hline Survey $1998 *$ Urban & $\begin{array}{l}1.367 * * \\
(0.478)\end{array}$ & $\begin{array}{c}1.111 \\
(1.253)\end{array}$ & $\begin{array}{c}0.811 \\
(0.617)\end{array}$ & $\begin{array}{c}0.871 * * * \\
(0.254)\end{array}$ & $\begin{array}{l}2.433 * * \\
(0.683)\end{array}$ & $\begin{array}{l}-0.213 \\
(0.316)\end{array}$ & $\begin{array}{c}0.511 \\
(0.404)\end{array}$ & $\begin{array}{l}1.743^{*} \\
(0.871)\end{array}$ & $\begin{array}{c}0.499 \\
(0.607)\end{array}$ \\
\hline HH Head FE & Yes & Yes & Yes & Yes & Yes & Yes & Yes & Yes & Yes \\
\hline HH Head FE * Urban & Yes & Yes & Yes & Yes & Yes & Yes & Yes & Yes & Yes \\
\hline Age in months FE & Yes & Yes & Yes & Yes & Yes & Yes & Yes & Yes & Yes \\
\hline Age in months $\mathrm{FE} *$ Urban & Yes & Yes & Yes & Yes & Yes & Yes & Yes & Yes & Yes \\
\hline Oblast FE & Yes & Yes & Yes & Yes & Yes & Yes & Yes & Yes & Yes \\
\hline Oblast*Urban FE & Yes & Yes & Yes & Yes & Yes & Yes & Yes & Yes & Yes \\
\hline $\mathrm{N}$ & 4303 & 1365 & 2938 & 4919 & 1579 & 3340 & 3966 & 1299 & 2667 \\
\hline R squared & 0.13 & 0.22 & 0.09 & 0.08 & 0.14 & 0.06 & 0.05 & 0.07 & 0.06 \\
\hline F-test & 0.755 & 12.257 & 4.394 & 0.643 & 1.153 & 2.596 & 3.143 & 2.449 & 2.559 \\
\hline $\mathrm{p}$-value & 0.659 & 0.004 & 0.035 & 0.740 & 0.434 & 0.116 & 0.052 & 0.150 & 0.119 \\
\hline
\end{tabular}

Notes: These are OLS regressions using the sample of children aged 0-60 months old at the time of the survey. "All", "0-24m" and "25-60m" refer to children aged 0-60, 0-24, and 25-60 months old, respectively, at the time of the survey. The regressions are estimated for the sub-sample of children living in rural areas. "Months exposed overall (including in utero period)" is the number of months a child was alive while land privatization was in place. The date of land reform (to calculate months of exposure) is based on the 2016 Life in Kyrgyzstan Study (which provided the month and year). All regressions include controls for household head age, gender, marital status, and ethnicity (Russian, Kyrgyz, Uzbek, with "other" being a reference group), a dummy for urban residence, child being female and an interaction term between "female" and "urban" indicators. Standard errors are clustered at the year of child birth level and appear in parentheses. ${ }^{*} \mathrm{p}<0.10,{ }^{*} \mathrm{p}<0.05,{ }^{* * *} \mathrm{p}<0.01$. "F-test" is the F-test result for testing for joint significance of coefficients estimated on interactions terms with "urban" indicator and the coefficient on urban indicator.

Source: World Bank LSMS (1993, 1996, 1997 and 1998) and Life In Kyrgyzstan Study (2016). 


\section{ALL IFPRI DISCUSSION PAPERS}

All discussion papers are available here

They can be downloaded free of charge

INTERNATIONAL FOOD POLICY RESEARCH INSTITUTE

www.ifpri.org

\section{IFPRI HEADQUARTERS}

1201 Eye Street, NW

Washington, DC 20005 USA

Tel.: +1-202-862-5600

Fax: +1-202-862-5606

Email: ifpri@cgiar.org 